\title{
The Residential Building Characteristics On-Site Inspection: Summary Report
}
S. A. Weakley
T. L. Howe
R. F. Darwin

June 1990

Prepared for the

Bonneville Power Administration

under a Related Services Agreement

with the U.S. Department of Energy

Contract DE-AC06-76RLO 1830

Pacific Northwest Laboratory

Operated for the U.S. Department of Energy

by Battelle Memorial Institute 


\title{
DISCLAIMER
}

This report was prepared as an account of work sponsored by an agency of the United States Government. Neither the United States Government nor any agency thereof, nor Battelle Memorial Institute, nor any of their employees, makes any warranty, expressed or implied, or assumes any legal liability or responsibility for the accuracy, completeness, or usefulness of any information, apparatus, product, or process disclosed, or represents that its use would not infringe privately owned rights. Reference herein to any specific commercial product, process, or service by trade name, trademark, manufacturer, or otherwise, does not necessarily constitute or imply its endorsement, recommendation, or favoring by the United States Government or any agency thereof, or Battelle Memorial Institute. The views and opinions of authors expressed herein do not necessarily state or reflect those of the United States Government or any agency thereof.

\author{
PACIFIC NORTHWEST LABORATORY \\ operated by \\ BATTELLE MEMORIAL INSTITUTE \\ for the \\ UNITED STATES DEPARTMENT OF ENERGY \\ under Contract DE-AC06-76RLO 1830
}

Printed in the United States of America

Available to DOE and DOE contractors from the

Office of Scientific and Technical Information, P.O. Box 62, Oak Ridge, TN 37831; prices available from (615) 576-8401. FTS 626-8401.

Available to the public from the National Technical Information Service, U.S. Department of Commerce, 5285 Port Royal Rd., Springfield, VA 22161.

NTIS Price Codes, Microfiche A01

Printed Copy

\begin{tabular}{cr}
\hline Price Code & Page Range \\
\hline A02 & $1-10$ \\
A03 & $11-50$ \\
A04 & $51-75$ \\
A05 & $76-100$ \\
A06 & $101-125$ \\
A07 & $126-150$ \\
A08 & $151-175$ \\
A09 & $176-200$ \\
A10 & $201-225$ \\
A11 & $226-250$ \\
A12 & $251-275$ \\
A13 & $276-300$ \\
A14 & $301-325$
\end{tabular}

\begin{tabular}{cc}
\hline Price Code & Page Range \\
\hline A15 & $326-350$ \\
A16 & $351-375$ \\
A17 & $376-400$ \\
A18 & $401-425$ \\
A19 & $426-450$ \\
A20 & $451-475$ \\
A21 & $476-500$ \\
A22 & $501-525$ \\
A23 & $526-550$ \\
A24 & $551-575$ \\
A25 & $576-600$ \\
A99 & $601-U p$
\end{tabular}


PNL -6429

UC -350

THE RESIDENTIAL BUILDING CHARACTERISTICS ON-SITE INSPECTION: SUMMARY REPORT

S. A. Weakley

R. F. Darwin

T. L. Howe

Manuscript Completed: December 1987

Date Published: June 1990

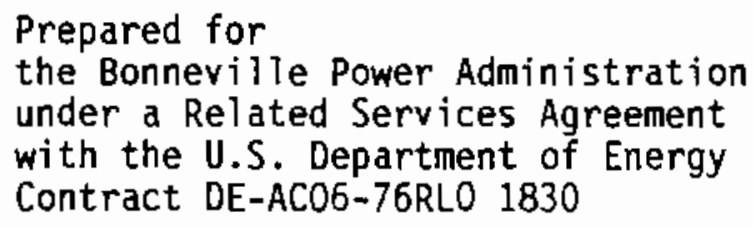

Pacific Northwest Laboratory

Richland, Washington 99352 


\author{
.
}

. 


\section{SUMMARY}

The Residential Building Characteristics On-Site Inspection (RI) was sponsored by the Bonneville Power Administration (BPA), and implemented by Energy Counselors, Inc., of Beaverton, Oregon. The purpose of the inspection was to collect detailed information on the structural characteristics and capital equipment of residences participating in BPA's End-Use Load and Conservation Assessment Program (ELCAP).

ELCAP is a long-term program to collect information on the structural characteristics of residences in the Pacific Northwest as well as the attitudinal, behavioral, and demographic characteristics of the residences' occupants. Combined with other data collection efforts, the information obtained by the RI will be used to assess and evaluate energy use and conservation within the region's residential sector.

This report documents the design of the inspection instruments (forms), the implementation of the inspection, and some of the results from the data base. The number of residences inspected was 416 or $93 \%$ of the potential sample of 447 residences.

The structural information gathered about each residence included detailed descriptions of each exterior wall, window, exterior door, foundation, ceiling/ roof, and floor. The capital equipment information inciuded details on each residence's HVAC system(s), refrigerator, freezer, dishwasher, and hot water heater as well as the total number of other appliances. For residences having an accessible crawl space, a detailed inspection of the crawl space was performed to identify potential moisture and/or insect problems. Other, general information obtained in the inspection included the age of the house, the type of dwelling unit, ventilation information, the number of levels in the house, the occupied area and volume, the number of rooms in the residence, and any modifications and/or additions that had been made to the residence since August 1983. All of the above information has been encoded and entered into the Characteristics Data Base at PNL. 


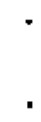




\section{CONTENTS}

SUMMARY

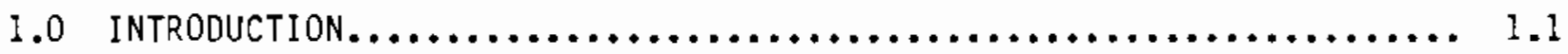

2.0 INSPECTION DESIGN AND IMPLEMENTATION $\ldots \ldots \ldots \ldots \ldots \ldots \ldots \ldots \ldots \ldots \ldots \ldots$

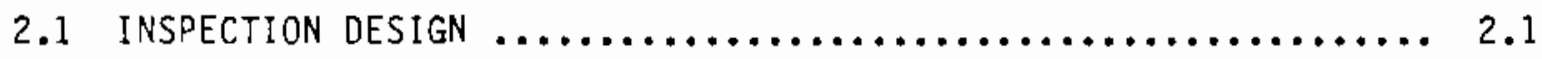

2.2 INSPECTION IMPLEMENTATION $\ldots \ldots \ldots \ldots \ldots \ldots \ldots \ldots \ldots \ldots \ldots \ldots \ldots \ldots \ldots \ldots \ldots$

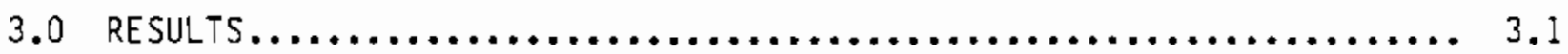

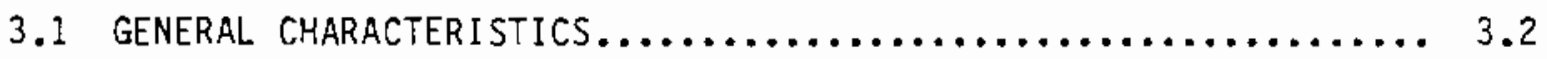

3.2 HVAC SYSTEM ChaRACTERISTICS $\ldots \ldots \ldots \ldots \ldots \ldots \ldots \ldots \ldots \ldots \ldots \ldots \ldots . \ldots \ldots$

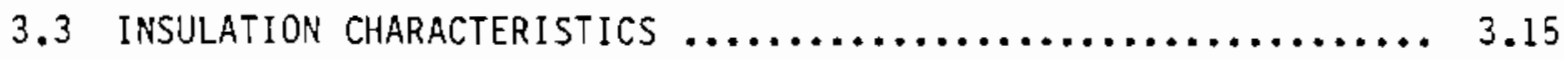

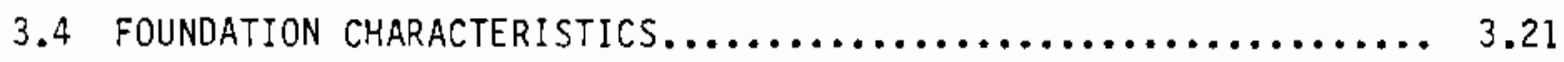

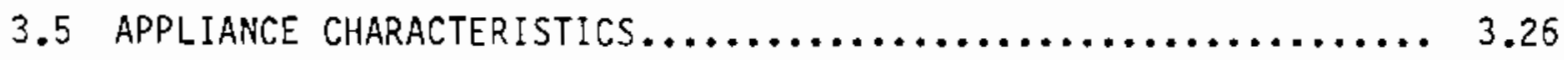

3.6 CRAWL SPACE INSPECTION RESULTS $\ldots \ldots \ldots \ldots \ldots \ldots \ldots \ldots \ldots \ldots \ldots \ldots . \ldots \ldots$

3.7 RECOMMENDATIONS............................ 3.32

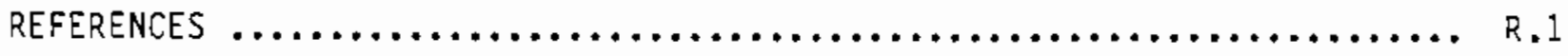

APPENDIX A - QUALITY ASSURANCE OF RESIDENTIAL INSPECTIONS ........... A.1 
EIGUPES

2.1 Postcard Sent to ElCAP Residents........................ 2.5

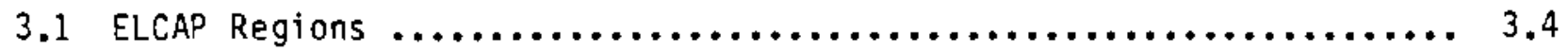




\section{TARLES}

3.1 Number of Inspected Residences by Study Type................. 3.1

3.2 General Characteristics of the 416 Inspected Residences........... 3.3

3.3 Conditioned Area of Dwelling by Year Built.................. 3.5

3.4 Geographic Location of Dwellings by year Built................ 3.5

3.5 Type of Residence by Year Built........................ 3.6

3.6 Geographic Location of Dwellings by Conditioned Area............ 3.7

3.7 Type of Residence by Conditioned Area..................... 3.7

3.8 Type of Residence by Geographic Location of Dwellings........... 3.8

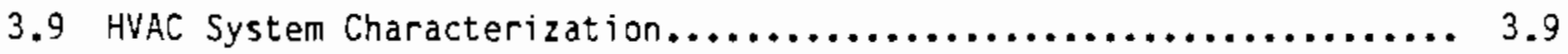

3.10 Heating System Type by Year Residence Built.................. 3.10

3.11 Heating System Type by Conditioned Area.................... 3.11

3.12 Heating System Type by Geographic Zone..................... 3.12

4.13 Heating System Type by Type of Residence $\ldots \ldots \ldots \ldots \ldots \ldots \ldots \ldots \ldots \ldots . \ldots . \ldots . \ldots 33$

3.14 Heating System Type by Wood Heating System................... 3.14

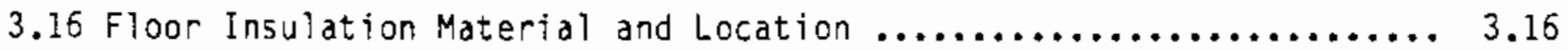

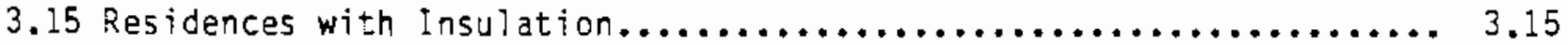

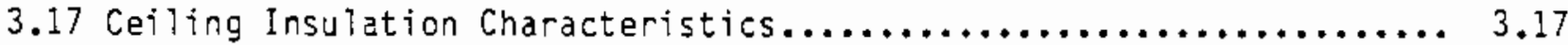

3.18 Ceiling Insulation Material by Year Residence Built............ 3.18

3.19 Ceiting Insulation Material by Conditioned Area ..................... 39

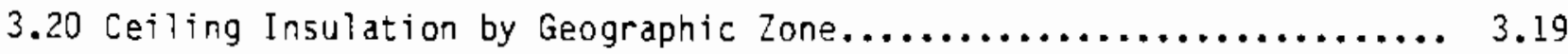

3.21 Ceiling Insulation Material by Type of Residence.............. 3.20

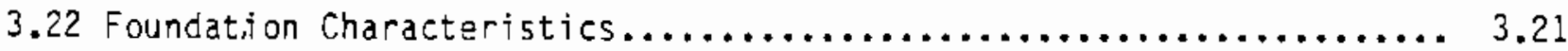

3.23 Foundation Type by Year Residence Built................... 3.22

3.24 Foundation Type by Conditioned Area $\ldots \ldots \ldots \ldots \ldots \ldots \ldots \ldots \ldots \ldots . \ldots \ldots$ 
3.25 Foundation Type by Geographic Zone......................... 3.24

3.26 Foundation Type by Type of Residence....................... 3.25

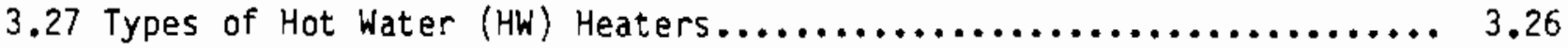

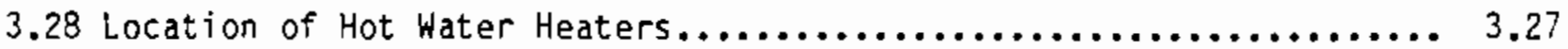

3.29 Capacity of Hot Water Heaters $. . \ldots \ldots \ldots \ldots \ldots \ldots \ldots \ldots \ldots \ldots \ldots \ldots \ldots, 3.27$

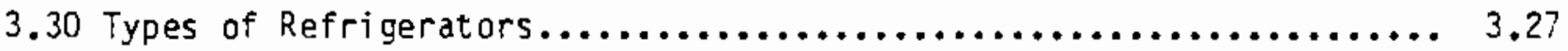

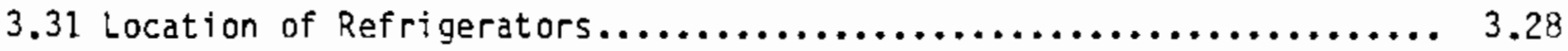

3.32 Types of Freezers...................................... 3.28

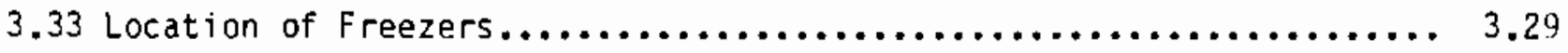

3.34 Other Appliances/Equipment Found in RI Houses.................. 3.29

3.35 Craw1 Space Problems.................................... 3.30

3.36 Crawl Space Problems by Geographic Zone $\ldots \ldots \ldots \ldots \ldots \ldots \ldots \ldots \ldots \ldots . .31$

3.37 Crawl Spaces Problems by Presence of Insulation................. 3.31

3.38 Crawl Space Problems by Presence of Vapor Barriers.............. 3.31 


\section{1.i) INTRODUCT.ION}

Electricity is an important energy resource in the Pacific Northwest. Adequately planning for the region's future electricity needs requires extensive information about how electricity is used by the region's consumers. The End-Use Load and Conservation Assessment Program (ELCAP) was launched by the Bonneville Power Administration (BPA) in September, 1983, to more fully understand the levels and patterns of electrical loads throughout the region, and to determine the size of the conservation resource in the region's residential and commercial sectors.

Under the ELCAP, 447 residences are being monitored with a Field Data Acquisition System (data logger) for hourly electricity consumption by end use. The residences are iocated throughout BPA's service area of Washington, Oregon, Idaho, western Montana, and Wyoming. The Residential Building Characteristics On-Site Inspection (RI) was developed and managed by the Pacific Northwest Laboratory (PNL) under contract to BPA in order to obtain detailed information on the structural characteristics and capital equipment of the ELCAP residences.

The RI Survey was conducted by Energy Counselors, Inc., of Beaverton, Oregon, over a one-year period from September 1985 through August 1986. In the first phase, 368 residences, or $82 \%$ of the total, were surveyed in less than four months. In the second phase 48 residences were surveyed over a threemonth period. All of the daca gathered were checked for accuracy and then entered in the Characteristics Deta Base (CDB) at PNL.

The results of the $R I$ will be used in combination with information obtained from other ELCAP surveys, such as the Residential Occupant Survey Mail (ROSM), the Residential Occupant Survey - ielephone (ROST), and the Residential Occupant Survey - Spring ' 86 (86R0S). The information obtained from these surveys and the RI has been entered into the Characteristics Data Base (COB) at PNL. The COB, in combination with the ELCAP Engineering Data 3ase, which contains the hourly electricity consumption of each residence by end use, will allow a number of analyses of residential sector electric energy use. Also, combining the data obtained from the RI with other survey results in tne 
ELCAP Fundanental Residential characteristics data hase will provide the energy analyst with a large data set of structural and appliance information and the attitudinal, behavioral and demographic characteristics of the residences' occupants.

This report provides both information on the development and implementation of the RI and on selected descriptive results. In Section 2.0 the survey's design and implementation are described. Section 3.0 summarizes the information obtained from the survey. 


\subsection{INSPECTION DESIGN AND IMPLEMENTATION}

In this section, the work that went into developing the inspection design is described and the inspection design and implementation of the inspection are reviewed. Problems encountered during the survey's implementation and actions taken to solve them are also discussed.

\subsection{INSPECTION DESIGN}

Design of the RI began in January 1985. A series of meetings between BPA and PNL personnel were held to determine the type and amount of information needed about each ELCAP residence. These meetings determined that an onsite inspection of each residence was required because of the large amount of structural and appliance information that was desired. A preliminary design for the RI was drawn up at PNL in January and February 1985 using input from PNL and BPA personne1. To aid in computer entry of the data, the answer forms for each inspection were separated from the questions themselves. The questions and the coded list of answers for each question were contained in a code booklet. The coded answers were entered on separate summary sheets that were to be used by data entry personnel to input them into the CDB. Separate floor plan sheets were included for each floor of the residence and were to contain the location of all windows, doors, stairs, HVAC equipment and major appliances.

Due to the detailed nature of the RI and to save cost, the inspectors did not calculate any overall heat-transfer values for the structural parts of the residence, i.e., for walls, floors, ceilings, etc. Instead, the inspectors recorded the areas of each wall, floor, etc., and the type of construction and insulation, if any. The insulation information included the type, material, thickness, and R-value. The R-values for various materials were included as an appendix to the code booklet so that each inspector would use the same values. With this information the analyst can calculate each overall heat-transfer coefficient.

In March and early April 1985, design work focused on refining the questions and the format of the summary sheets. After the code booklet and 
associated sumnary sheets were refined, they were field tested on eight ELCAP base-case residences. During and immediately following the eight inspections, two new versions of the code booklet were made. Small changes that the inspectors noted were then incorporated. However, one major problem remained with the inspection: how to handle multiple heating systems in one residence.

BPA and PNL personnel resolved the problem at an April 15, 1985, meeting by deciding that each major heating system would have an associated zone or area of the house identified with it. This zone was labeled and mapped on the floor plan and identified with a particular heating system on the computer summary sheets. Minor heating systems contained within a major heating system zone were to be identified and labeled as a subzone on the floor plan and the summary sheets. The area and volume of these zones and subzones were also to be included on the summary sheets as conditioned areas. Other additions to the floor plan made at that time included the orientation of the house, the length of all perimeter walis, the average ceiling height, and the square footage of each floor.

Two other changes were also made to the code booklet at the meeting. The first was a change in the location part of several of the questions in the code booklet. After zoning was approved, the codes for conditioned and unconditioned zones could be used to identify the locations of doors, walls, windows, floors, HVAC equipment and appliances in the house. In addition to the zone codes for location questions, the foliowing alphanumeric symbols were adopted for the entire code booklet: A for Attic, CS for crawl space, 0 for Outside, MF for Multi-Family, and $G$ for Ground. The second change to the code booklet was the addition of an insulation-type question to wall, ceiling/roof, and floor questions. Previousiy, only the insulation material was requested, not the type or form of the insulation, i.e., batt or blanket, loose or blown-in, loose fill in confined cavity, and board or slab.

At the April 15 meeting, a new section entitied "Modifications and Additions Questions" aiso was added to the RI. The eight questions in the section related to changes or additions the residents may have made to their houses since the summer of 1983. These questions were designed to update an earlier 
BPA study, the 1983 Pacific Northwest Residential Energy Survey. The residents' answers to these questions were recorded on separate sheets rather than on the summary sheets. These data were not entered into the computer data base. All of the changes made to the RI design document resulting from the April 15 meeting were completed by mid-June 1985 .

On April 19, 1985, BPA requested a feasibility study of the inspectors using microcomputers in the field to enter the RI results. Using microcomputers would have allowed the data to be directly input to the data base rather than on summary sheets or forms. The study results were sent to BPA on May 15, 1985. BPA recommended that the data be entered on paper by the inspectors in the field and entered on the computer data base by PNL staff. The microcomputer entry from the field was seen as being too expensive and of unknown quality compared with the recommended procedure.

On May 31, 1985, BPA decided that residents being monitored as part of their Residential Standards Demonstration Project (RSDP) would also be inspected. This added 111 more residences to the survey for a total of 447 .

In July 1985 the inspection of all accessible crawl spaces was included as part of the residential survey in order to identify crawl spaces that had moisture and/or insect problems. As a result of this addition, questions dealing with the exterior contact of the walls and foundation with shrubs, trees and earth were added to the code booklet because these exterior contacts were seen to be ways that insects may enter the walls or foundation. Another sign of insect presence may be sill decay, which was also included as a window question. A question on the accessibility of the crawl space, if one was present, was also added to the code booklet. If the crawl space was accessible, then four more questions were to be answered dealing with water run off and the crawl space vents, entry and odor. Each accessible craw space was to be diagrammed on a separate sheet with all problems and their locations identified. If more information were obtained, it was to be recorded on a separate page called Inspector Comments.

The September 1985 version of the code booklet and summary sheets included all of the above crawl space changes as well as some simpler changes. Two 
changes were 7ade to the grocedures manua?, which was to he used by the inspectors in the field. One change was that the floor plan of the kitchen was to be drawn separately from the rest of the house, with the distance between the refrigerator, stove, oven and/or range noted on the diagram. This information was to be used to judge the effect of these appliances use on each other. One other change was the decision not to subzone for wood stoves and fireplaces.

The September 1985 version of the survey was field tested during the first week in 0ctober 1985. The 20 pilot surveys were reviewed at a meeting with BPA and PNL staff, and the inspectors. Resulting from this october meeting was an agreement on the final version of the procedure manual, code booklet, and all forms. One change was to include a separate kitchen diagram form in each survey. The crawl space diagram was modified to include some idea of the severity of the problems encountered. Two questions were added to the "Modifications and Additions Questions" section concerning small businesses being run in the house and whether the data logger is labeled properiy. The code booklet itself was essentially unchanged after the pilot surveys.

The final revision of the survey was published as an ELCAP document entitled Procedures Manual for ELCAP Residential Building Characteristics Survey (BPA 1986). Inciuded in that report are al1 forms and the code booklet used by the field inspectors.

\subsection{INSPECTION IMPLEMENTATION}

In June 1985, eight companies were sent a Request for Proposal (RFP) for collecting field data from the residential ELCAP participants. The RFP consisted of a statement of work, quality assurance requirements, evaluation criteria to be used in evaluating the RFP, and other solicitation and general provisions. Seven of the eight companies submitted proposals in July 1985 and a source evaluation team composed of five PNL researchers reviewed the proposals according to the evaluation criteria sent with each RFP. Energy Counselors, Inc. (ECI), of Beaverton, Oregon, was selected by the evaluation team to perform the onsite data collection. A contract with ECI was finalized in August 1985. 
Rocause an insoection of a! l accessihle crawl spacus was atdad to tha Pi, a supplement to the contract with ECI was negotiated and then signed in September 1985. Also in September PNL sent each ELCAP resident a postcard reminding them of the inspection and identifying ECI as the firm that would conduct the inspection. A copy of this postcard is shown in Figure 2.1 .

In September two other tasks were also added to the inspection. The first task was to photograph each temperature sensor inside and outside the home and to also photograph the Northern exposure of the house and the meteorological station, if one was present. The second task was to affix a U.S. Government property sticker to the Field Data Acquisition System (FDAS) (ELCAP's electricity monitor) or data logger if one was not present on the unit. The cameras and FDAS stickers were given to ECI with instructions in September.

A training session for the ECI inspectors was heid on September 23, 1985, in Portland, Oregon. The survey forms were distributed and discussed line by line; instructions were given on completing the floor plan sheets and zoning set-up; and an overview was given of the ELCAP. A session on how to gather the appliance information was given by BPA personnel, and a special session on identifying insect and moisture problems in crawl spaces was presented by a

\title{
sive Battelle
}

\begin{abstract}
A Residential Building Survey (inspection) for the homes in your region has been scheduled to begin atter $10 / 1 / 85$ and will be performed by:
\end{abstract}

\section{Energy Counselors, Inc. 7873 S.W. Cirrus Drive Beaverton, Oregon}

\begin{abstract}
A representative of the firm will contact you soon to arrange
\end{abstract} for a specific time to periorm the work.

Paciinc . vor hwest Laboratory is operated tor the L'.S. Deparment of Energy by Battelie stemortai Instisute

FIGURE 2.1. Postcard Sent to ELCAP Residents 
consultant. At the meeting it was decided that the pilot study sample of 20 residences would be done in the Portland, Oregon, area beginning in October 1985.

During the first week in October 1985, 20 residences in the Portland, Oregon, area were inspected by Energy Counselors, Inc., (ECI) personnel. The results were sent to PNL and analyzed over the next two weeks. Minor changes to the survey's design were made. The final survey design changes were completed by October 20, 1985, and the new forms, code booklets, and floor plan sheets were then sent to ECI.

As a result of the pilot study, a brochure describing ELCAP was sent to all ELCAP residences to aid in site relations between ECI and the residents and to describe in more detail the importance of the inspection. The brochure was prepared and sent to the residents at the end of November 1985 . The ECI inspectors also were given some of the brochures to hand to any residents who had not yet received theirs.

Phase I of the RI began in the field on October 29, 1985, and lasted until February 15, 1985. Over the 14-week period of Phase I, most of the regions of the ELCAP area were to be visited for inspection only once. During Phase I of the RI, 368 residences were inspected by ECI. Of the remaining 79 residences, only 6 residences refused to admit ECI for the RI.

As Phase II of the RI, ECI attempted to visit the 79 residences that were not inspected in Phase I.

Phase II of the RI began in the field on June 2, 1986, and was completed on August 28,1986 . All surveys from Phase II were received at PNL by September 10, 1986, and entered into the data base by the end of September. As part of Phase II, 48 residences were surveyed. The survey forms and documents were the same as used in Phase $I$.

By the end of Phase II, 31 residences had not been inspected and 416 had been inspected, representing a success rate of $93 \%$. Of the 31 residences not inspected, 10 residents refused to allow ECI to inspect their house, 9 were unable to schedule a time for ECI to inspect, and 12 residences could not be inspected because PNL had not signed access agreements with the owners and/or renters. 
After the surveys were sent to PNL, a Quality Assurance (QA) inspection of the data was performed. Appendix A details the QA procedures followed at PNL. If major problems were encountered with any surveys, they were sent back to ECI with questions for interpretation. In most cases the inspectors, after reviewing the returned survey, were able to resolve any problems encountered.

After passing the QA examination, the surveys were submitted to data processing for entry into the CDB. Any questions that the data entry personnel had were resolved before final entry occurred. To assure that all data were entered into the CDB correctly, a double entry QA process was used. This involved two data entry personnel entering the same data and then checking for any differences.

Most of the computerized data were entered into the main data base (the CDB). Three other data bases, however, also were created and/or changed at PNL as a result of the RI. The crawl space data were entered into a separate data base for later analysis. Also, some of the information on the crawl space diagram was encoded and entered in this data base. All ECI and customer comments recorded on the survey's "Inspector Comments" sheet were entered into a separate data base, ANALNOTES. Finally, the date that ECI inspected the residence was entered into the FIXNOTES subdirectory. The FIXNOTES subdirectory is used to keep track of all site visits to ELCAP residences.

In addition to the above computer data bases, there are also paper copies of much of the above data. The survey forms, floor plan sheets, photographs and comment sheets are stored at PNL in their original form for future reference. All of the QA questions about each survey and changes made to the ECI inspectors' survey forms made at PNL were written down and are also stored at PNL. These written documents also serve as backup to the CDB as well as original documents of the RI.

The residents' comments that were recorded by the ECI inspectors primarily dealt with structural details about the house, such as insulation type and thickness, heating systems most often used, etc. The most common nonstructura? comments were requests for results or information about the energy uses in the house and questions about when the ELCAP metering would be finished. Some 
complaints were also received that there were too many visits from ELCAPrelated personnel. This was also the primary reason given by the 10 residents who refused to allow ECI to inspect their houses. Other than this complaint, most of the residents were very cooperative and helpful to the ECI inspectors. 


\section{?.) PESILTS}

This chapter summarizes the information obtained from the RI and contained in the CDB. The intent of this discussion is to give a brief description of the inspected dwellings' structural and appliance characteristics.

The residences that participated in the RI are from seven different samples or studies, and the following results cannot be generalized to other populations. Table 3.1 shows the seven studies and the number of inspected residences in each study. The ELCAP base case comprises $64 \%$ of the total residences inspected. The current code (CC) Study residences are new houses built to their state's existing codes. The Model Conservation Standard (MCS) Study residences are new homes built to meet new, stricter codes for residential construction in the Pacific Northwest. The residences from the CC and MCS studies comprise $25 \%$ of the total residences in the RI. The other studies each make up less than $10 \%$ of the total residences inspected. The final subcategory shown is not a study but is the total number of residences that have dropped from the ELCAP.

Section 3.1 reviews and summarizes the following general characteristics of all the inspected residences in the CDB: the ages of the residences, the conditioned square footage of the residences, the geographic dispersion of the dwellings, and the types of residences. Sections 3.2 through 3.5 present

TABLE 3.1. Number of Inspected Residences by Study Type

$\frac{\text { Study Type }}{\text { ELCAP Base Case }}$
Condominiums
Renter Occupied
Mobile Home
Gas/0il Heat
Current Code
ModeT Conservation Standard
Dropped from ELCAP

Number of

Residences 267
Percentage of Residences 64

0.5 2 2 5 7 18 
informatinn ahnit, the residences. HVAC systoms, insulatinn, foindations, and appliances. In addition, the structural and HVAC information is related to the general characteristics defined in Section 3.2. Section (3.6) discusses the crawl space survey results, and a recommendation's section ends the chapter.

\subsection{GENERAL CHARACTERISTICS}

Table 3.2 shows 5 general characteristics categories for the 416 inspected residences: year the residences were built, the conditioned area of the residences, the geographic regions and zones where the residences are located, and the type of residences. Each of these general characteristics categories is broken into several subcategories that show the number of residences and the corresponding percentage of residences within each subcategory.

As the year built category shows, the number of residences inspected was almost evenly divided among the three time periods; the pre-1960 subcategory had slightly fewer residences than the other two subcategories. In the conditioned area category, smaller houses, <1000 $\mathrm{ft}^{2}$, accounted for only $12 \%$ of the residences inspected, whereas the other three subcategories were eveniy divided at $\sim 30 \%$ of the population each.

The 22 geographic regions 1 isted in Table 3.2 are mapped in Figure 3.1 and can be grouped into three zones. Zone $\# 1$ consists of western Washington and western Oregon and encompasses Regions 11-18. Zone $\# 2$ consists of eastern Washington, eastern 0regon, Idaho, and a small part of Wyoming and encompasses Regions 3-10, 19,20, 21 and 22. Geographic zone $\# 3$ is western Montana and is made up of residences in Regions 1 and 2 . Geographic zone $\cong 3$ contains only $10 \%$ of the residences, but the remaining $90 \%$ is almost evenly split between zones 1 and 2 .

The type of residences which responded to the RI are also shown in Table 3.2. The types are divided into single-family dwellings, split further by the number of stories, including split level and mobile homes, and multifamily dwellings, further split by the number of units in the complex. Onestory singie-family dwellings make up $56 \%$ of the residences in the inspection. The 1-1/2 and 2-story single-family dwellings make up $31 \%$ of the residences 
TARLE 3.2. General Characteristics of the 415 Inspected Positences

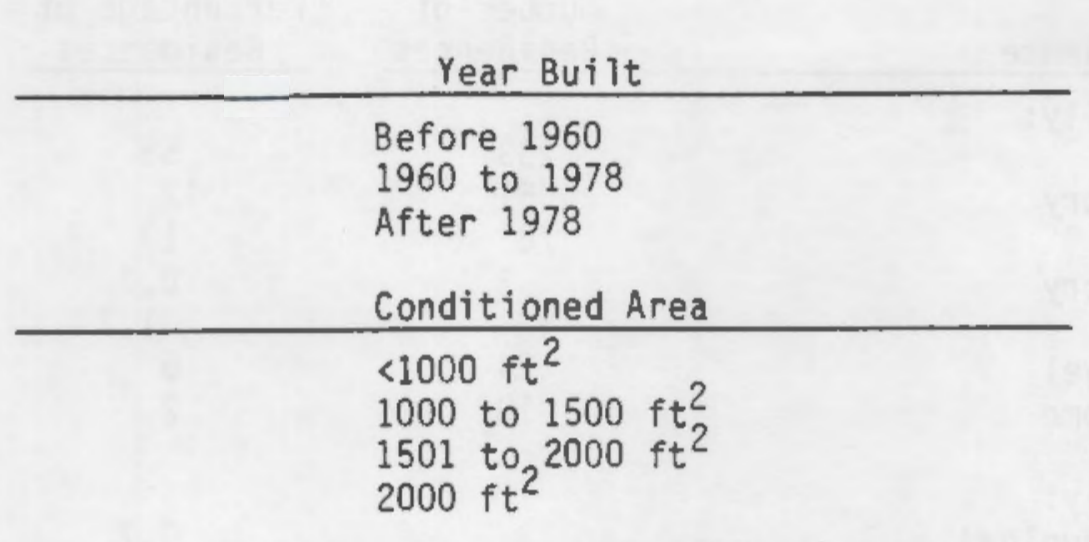

\begin{tabular}{|c|c|}
\hline $\begin{array}{l}\text { Number of } \\
\text { Residences }\end{array}$ & $\begin{array}{l}\text { Percentage of } \\
\text { Residences }\end{array}$ \\
\hline $\begin{array}{l}111 \\
160 \\
145\end{array}$ & $\begin{array}{l}27 \\
38 \\
35\end{array}$ \\
\hline
\end{tabular}

Geographic Region(a)

1
2
3
4
5
6
7
8
9
10
11
12
13
14
15
16
17
18
19
20
21
22

$\begin{array}{rr}31 & 7 \\ 13 & 3 \\ 18 & 4 \\ 25 & 6 \\ 21 & 5 \\ 5 & 1 \\ 32 & 8 \\ 1 & 0.2 \\ 7 & 2 \\ 11 & 3 \\ 11 & 3 \\ 12 & 3 \\ 46 & 11 \\ 36 & 9 \\ 39 & 9 \\ 7 & 2 \\ 25 & 6 \\ 14 & 3 \\ 8 & 2 \\ 15 & 4 \\ 11 & 3 \\ 28 & 6\end{array}$

Geographic Zone

\footnotetext{
$\# 1$ = Western Oregon + western Washington

$\# 2$ = Eastern Oregon + eastern Washington + Idaho + Wyoming

$\# 3$ = Western Montana
}

190

46

182

44

44

10

(a) See Figure 4.1 for map regions. 
TABLE 3.2. (contd)

Type of Residence

Single Family:

1 Story

1 1/2 Story

2 Story

$21 / 2$ Story

3 Story

Split Level

Mobile Home

Multi-Family:

2 Unit (duplex)

4 Unit

5 or More Unit \begin{tabular}{l}
$\begin{array}{l}\text { Number of } \\
\text { Residences }\end{array} \quad \begin{array}{l}\text { Percentage of } \\
\text { Residences }\end{array}$ \\
\hline
\end{tabular}

56

233

51

78

$4^{3}$

24

10

12

19

0.7

1.7

6

2

0.7

2

0.2

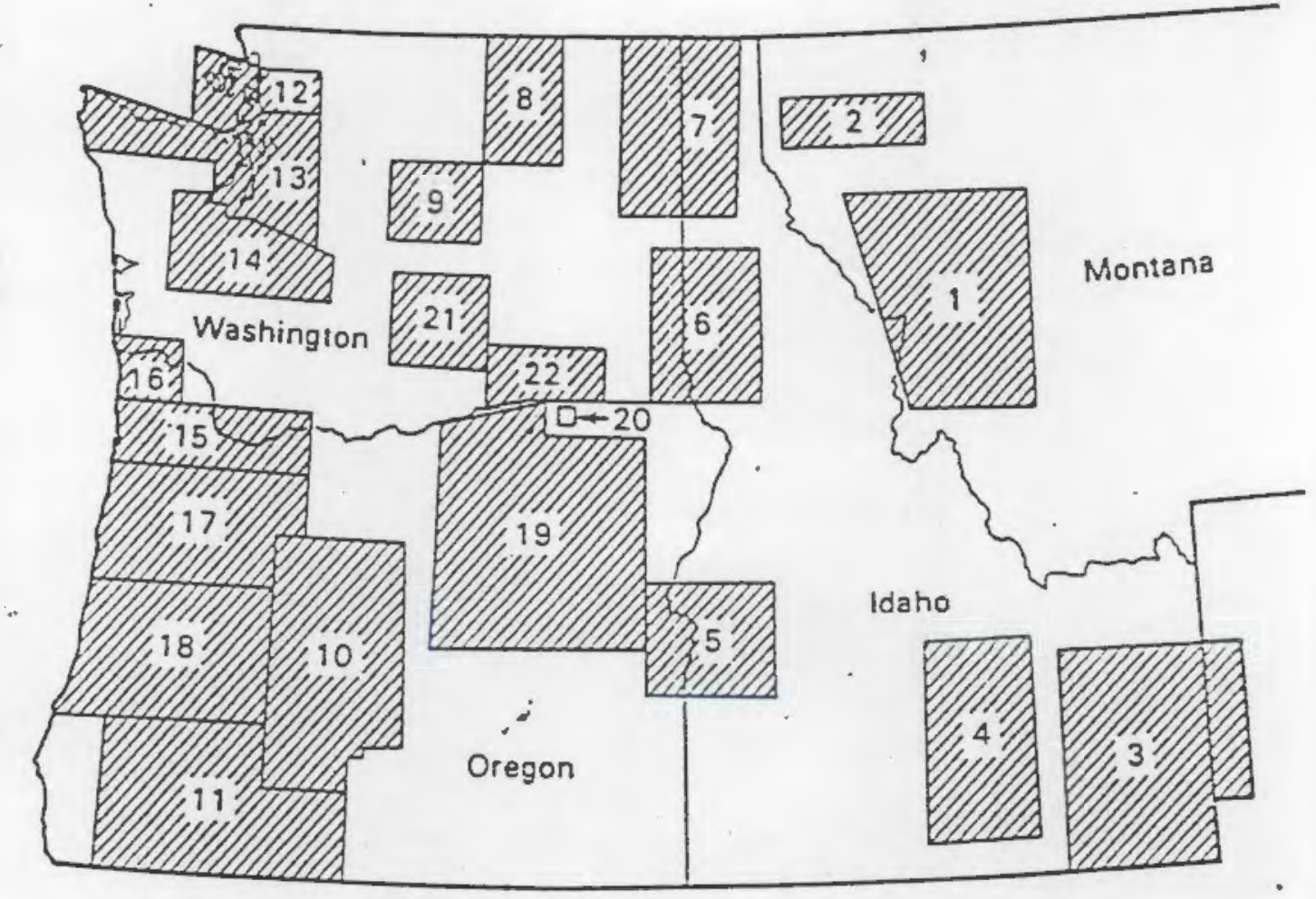

FIGURE 3.1. ELCAP Regions 
inspocted. The remaining 13 is is divided among tho nthom 7 sidhcategories, with only $3 \%$ of the residences being multi-family dwellings.

The rest of this section shows how the characteristic categories listed in Table 3.2 interrelate with each other. Table 3.3 shows that the smaller houses, those with $<1000 \mathrm{ft}^{2}$ of conditioned space, make up a larger percentage of older homes than of newer ones. The other three subcategories of conditioned area are about the same over time, with only a slight increase in larger houses, $>2000 \mathrm{ft}^{2}$, being built in the 1960 to 1978 time span.

Table 3.4 examines the residences' geographic distribution by year built. In geographic zone \#3, the proportion of houses built after 1978 is much larger than for the other two earlier time spans. The remainder of the residences are eventy split in each time span between geographic zones 1 and 2, although there are slightiy more residences in geographic zone $\# 1$ than in $\frac{\| 2}{\pi}$ for the 1960 to 1978 time span.

TABLE 3.3. Conditioned Area of Dwelling by Year Built

\begin{tabular}{cccc}
$\begin{array}{c}\text { Conditioned } \\
\text { Area }\end{array}$ & $\begin{array}{c}\text { Bear Built } \\
1960 \\
(n=111)\end{array}$ & $\begin{array}{c}\text { Ye60 to } \\
1978\end{array}$ & $\begin{array}{c}\text { After } \\
1978\end{array}$ \\
\hline$<1000 \mathrm{ft}^{2}$ & $\frac{(n=160)}{6 \%}$ & $\frac{(n=145)}{12 \%}$ \\
1000 to $1500 \mathrm{ft}^{2}$ & $29 \%$ & $33 \%$ & $30 \%$ \\
1501 to $2000 \mathrm{ft}^{2}$ & $25 \%$ & $25 \%$ & $29 \%$ \\
$>2000 \mathrm{ft}^{2}$ & $25 \%$ & $35 \%$ & $29 \%$
\end{tabular}

TABLE 3.4. Geographic Location of Dwellings by Year Built

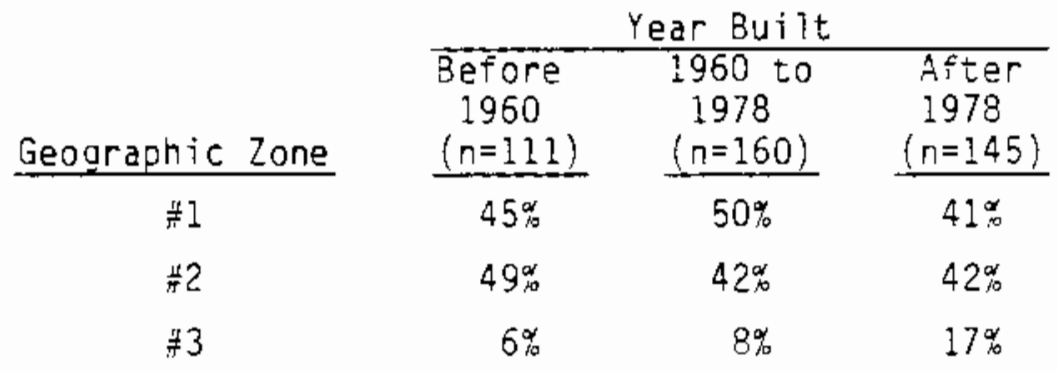




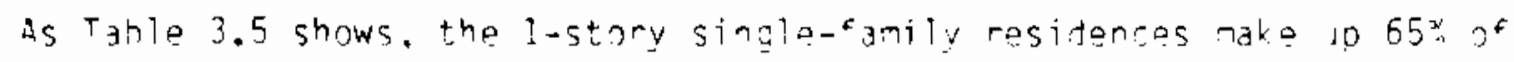
the older, pre-1960 built houses in the RI. Of the remaining older homes, the $1-1 / 2$ and 2-story houses account for all but $4 \%$ of the total. In the 1960 to 1978 time span, the one-story single-family house still dominates with $62 \%$ of the total residences in this subcategory. Two-story houses still comprise $18 \%$ of the total but now the 1-1/2 story, mobile homes, and split-level houses each make up $\sim 6 \%$ of the total. Finally in the new houses, post 1978, the singlefamily houses represent $43 \%$ of the total, with the $1-1 / 2$ and 2 -story homes each comprising $\sim 20 \%$. The split-level houses increased in this time span to $9 \%$ of the total, while the multi-family, 4-unit complex represented $5 \%$ of the residences.

As shown in Table 3.6, more of the smaller homes $\left(<1000 \mathrm{ft}^{2}\right)$ are in geographic zone \#2 than in the other two zones. In the 1000 to $1500 \mathrm{ft}^{2}$ conditioned area subcategory, $60 \%$ of the houses are in geographic zone \#1, while in the 1501 to $2000 \mathrm{ft}^{2}$ subcategory the number of residences is evenly split

TABLE 3.5. Type of Residence by Year Built

\begin{tabular}{|c|c|c|c|}
\hline \multirow[b]{2}{*}{ Tyoe of Residence } & \multicolumn{3}{|c|}{ Year Built } \\
\hline & $\begin{array}{c}\text { Before } \\
1960 \\
(n=111) \\
\end{array}$ & $\begin{array}{c}1960 \text { to } \\
1978 \\
(n=150)\end{array}$ & $\begin{array}{l}\text { After } \\
1978 \\
(n=145) \\
\end{array}$ \\
\hline \multicolumn{4}{|l|}{ Single Fanily: } \\
\hline One-Story & $65^{\circ}$ & $62 \%$ & $43 \%$ \\
\hline $1-1 / 2$ Stary & $16_{\%}^{*}$ & $6^{\infty}$ & $16 \%$ \\
\hline Two Story & $15 \%$ & $13^{x}$ & $22 \%$ \\
\hline $2-1 / 2$ Story & $1 \%$ & $1 \stackrel{\alpha}{\sigma}$ & $l_{0}^{\infty}$ \\
\hline Three Story & $1 \%$ & $0 \%$ & $2 \%$ \\
\hline Split Level & 10 & $6 \%$ & $9 \%$ \\
\hline Mobile Home & $0 \%$ & $5 \%$ & $1 \stackrel{\alpha}{\%}$ \\
\hline \multicolumn{4}{|l|}{ Multi-Family: } \\
\hline 2-Unit (Duplex) & $1 \%$ & $1 \%$ & $0 \%$ \\
\hline 4-Unit & $0 \%$ & $1 \%$ & $5 \%$ \\
\hline 5 or More Unit & $0 \%$ & $O_{n}^{*}$ & $1 \%$ \\
\hline
\end{tabular}


TAR:L 3.6. Feographic Lncation of Twellings by ronditionet aroa

Conditioned Area

\begin{tabular}{|c|c|c|c|c|}
\hline \multirow[b]{2}{*}{ Geographic Zone } & \multicolumn{4}{|c|}{ ( } \\
\hline & $\begin{array}{l}<1000 \mathrm{ft}^{2} \\
(n=49)\end{array}$ & $\begin{array}{c}1000-1500 \mathrm{ft}^{2} \\
(\mathrm{n}=129)\end{array}$ & $\begin{array}{c}1501-2000 \mathrm{ft}^{2} \\
(n=111)\end{array}$ & $\begin{array}{l}>2000 \mathrm{ft}^{2} \\
(n=127) \\
\end{array}$ \\
\hline$\# 1$ & $37 \%$ & $60 \%$ & $46 \%$ & $34 \%$ \\
\hline$\# 2$ & $53 \%$ & $30 \%$ & $50 \%$ & $49 \%$ \\
\hline \#3 & $10 \%$ & $10 \%$ & $4 \%$ & $17 \%$ \\
\hline
\end{tabular}

between geographic zones \#1 and \#2. More of the residences in geographic zone \#3 are larger houses $\left(>2000 \mathrm{ft}^{2}\right)$, as evidenced by the fact that $17 \%$ of that subcategory is in geographic zone $\# 3$.

Table 3.7 examines the relationship between house type and size of conditioned area. In all size subcategories, the single-family, l-story residence predominates, but the percentage of 1 -story houses falls from $70 \%$ in the smaller houses $\left(<1000 \mathrm{ft}^{2}\right)$ to $44 \%$ in the larger homes $\left(>2000 \mathrm{ft}^{2}\right)$. As

\section{TABLE 3.7. Type of Residence by Conditioned Area}

\begin{tabular}{|c|c|c|c|c|}
\hline \multirow[b]{2}{*}{$\begin{array}{l}\text { Type of } \\
\text { Residence }\end{array}$} & \multicolumn{4}{|c|}{ Conditioned Area } \\
\hline & $\begin{array}{l}<1000 f t^{2} \\
(n=49)\end{array}$ & $\begin{array}{c}1000-1500 \mathrm{ft}^{2} \\
(\mathrm{n}=129)\end{array}$ & $\begin{array}{c}1501-2000 \mathrm{ft}^{2} \\
(n=111)\end{array}$ & $\begin{array}{l}>2000 \mathrm{ft} t^{2} \\
(n=127)\end{array}$ \\
\hline \multicolumn{5}{|l|}{ Single-famity: } \\
\hline One-Story & $76 \%$ & $70 \%$ & $45 \%$ & $44 \stackrel{\alpha}{\%}$ \\
\hline $1-1 / 2$ Story & $0 \%$ & $15 \%$ & $13 \not \infty$ & $14_{\%}^{\sim \alpha}$ \\
\hline Two-Story & $0 \%$ & $9 \%$ & $27 \%$ & $28 \%$ \\
\hline $2-1 / 2$ story & $0 \%$ & $0 \%$ & $0 \%$ & $2 \%$ \\
\hline Three-Story & $0 \%$ & $0 \%$ & $0 \%$ & $3 \%$ \\
\hline Split-Level & $0 \%$ & $3 \%$ & $10 \%$ & $7 \%$ \\
\hline Mobile Home & $6 \%$ & $3 \%$ & $3 \%$ & $0 \%$ \\
\hline \multicolumn{5}{|l|}{ Multi-Famity: } \\
\hline 2-Unit (Duplex) & $2 \%$ & $0 \%$ & $1 \%$ & $1 \%$ \\
\hline 4-Unit & $16 \%$ & $0 \%$ & $0 \%$ & $1 \%$ \\
\hline 5 or More Unit & $0 \%$ & $0 \%$ & $1 \%$ & $0 \%$ \\
\hline
\end{tabular}


expected, the 2, 2-1/2 and 3-story residences are moro prevalent in the larges: subcategory (>2000 $\mathrm{ft}^{2}$ ). The $1-1 / 2$ story houses make up $\sim 14 \%$ of the three subcategories above $1000 \mathrm{ft}^{2}$, while the split leve? homes are more prevalent in the 1501 to $2000 \mathrm{ft}^{2}$ subcategory. Mobile homes and all of the smaller multifamily complexes ( $<4$ units) are more common in the smaller residences $\left(<1000 \mathrm{ft}^{2}\right)$ subcategory.

The single-family, 1-story building, as shown in Table 3.8 , is the predominant type of residence in all three geographic zones, comprising $\sim 55 \%$ of the total houses in each. The single-family, 2-story building represents $\sim 18 \%$ of all houses in each geographic zone. Percentage-wise there are fewer 1-1/2 story buildings but more multi-family dwellings in geographic zone \#2. A sso, geographic zone $\# 3$ has no $2-1 / 2$ or 3 story houses, mobile homes, or multi-family dwellings in the RI.

IABLE 3.8. Type of Residence by Geographic Location of Dwellings

\begin{tabular}{|c|c|c|c|}
\hline $\begin{array}{l}\text { Type of } \\
\text { Residence }\end{array}$ & $\begin{array}{c}\# 1 \\
(n=190) \\
\end{array}$ & $\begin{array}{c}\frac{\pi}{\pi 2} \\
(n=182) \\
\end{array}$ & $\begin{array}{c}13 \\
(n=44) \\
\end{array}$ \\
\hline \multicolumn{4}{|l|}{ Single-Fami ly: } \\
\hline One-Story & $56 \%$ & $54 \%$ & $54 \%$ \\
\hline $1-1 / 2$ Story & $15 \%$ & $8 \%$ & $20 \%$ \\
\hline Two-Story & $17 \%$ & $19 \%$ & $18 \%$ \\
\hline 2-1/2 Story & $2_{\infty}^{\alpha}$ & $0 \%$ & $0 \%$ \\
\hline Three-Story & $1 \%$ & $2 \%$ & $0 \%$ \\
\hline Split-Level & $5 \%$ & $7 \%$ & $8 \%$ \\
\hline Mobile Home & $3 \%$ & $3 \%$ & $0 \%$ \\
\hline \multicolumn{4}{|l|}{ Multi-Fami 1y: } \\
\hline 2-Unit (Ouplex) & $1 \%$ & $1 \%$ & $0 \%$ \\
\hline $4-$ Unit & $0 \%$ & $5 \%$ & $0 \%$ \\
\hline 5 or More Unit & $0 \%$ & $1 \%$ & $0 \%$ \\
\hline
\end{tabular}




\subsection{UVAC SYSTEM CHARACTERISTICS}

All of the 416 ELCAP residences surveyed in the RI contain at least one of the following heating systems: electric forced air, heat pump, radiant heat, gas heat, oil heat, or electric resistance heat. Table 3.9 shows the number of residences that contain each of these heating systems. As the table shows, 71 residences contain two heating systems, while the remaining 345 residences contain only one system. The most common heating system is electric resistance heating, with 44\% of the RI sample having only this source of heat in the dwelling. Electric resistance heat also is the secondary heat source for 64 residences $(15 \%)$.

Of the other heating systems, electric forced air is used by 89 residences as the only heat source and in combination with radiant heat in 2 residences. Sixteen residences have an electric forced air system and also electric resistance heat. Heat pump systems for heating and cooling are used by 36 residences as the only heat source and by 6 residences in combination with another

TABLE 3.9. HVAC System Characterization

\begin{tabular}{|c|c|c|}
\hline Heating System & $\begin{array}{l}\text { Number of } \\
\text { Residences } \\
\quad(n=416) \\
\end{array}$ & $\begin{array}{c}\begin{array}{c}\text { Number with } \\
\text { Air Conditioning } \\
(n=118)\end{array} \\
\end{array}$ \\
\hline $\begin{array}{l}\text { Electric Forced Air (oniy) } \\
\text { Electric w/Electric Resistance Heat } \\
\text { Electric w/Radiant Heat }\end{array}$ & $\begin{array}{rr}89 & (21 \%) \\
16 & (4 \%) \\
2 & (0.5 \%)\end{array}$ & $\begin{array}{rr}37 & (31 \%) \\
5 & (4 \%) \\
1 & (1 \%)\end{array}$ \\
\hline $\begin{array}{l}\text { Heat Plimp (only) } \\
\text { Heat w/Electric Resistance Heat } \\
\text { Heat w/Oil Heat } \\
\text { Heat } w / \text { Radiant Heat }\end{array}$ & $\begin{array}{rr}36 & (9 \%) \\
3 & (1 \%) \\
2 & (0.5 \%) \\
1 & (0.25 \%)\end{array}$ & $\begin{array}{rr}35 & (31 \%) \\
3 & (3 \%) \\
2 & (2 \%) \\
1 & (1 \%)\end{array}$ \\
\hline $\begin{array}{l}\text { Radiant Heat (only) } \\
\text { Radiant w/Electric Resistance Heat } \\
\text { Radiant w/Oil Heat }\end{array}$ & $\begin{array}{rr}18 & (4 \%) \\
28 & (7 \%) \\
1 & (0.25 \%)\end{array}$ & $\begin{array}{ll}1 & (1 \%) \\
5 & (4 \%) \\
0 & (0 \%)\end{array}$ \\
\hline $\begin{array}{l}\text { Gas Heat (oniy) } \\
\text { Gas w/Electric Resistance Heat } \\
\text { oil Heat (only) } \\
0 i l \text { w/Electric Resistance Heat }\end{array}$ & $\begin{array}{l}(3 \%) \\
(3 \%) \\
(1 \%) \\
(1 \%)\end{array}$ & $\begin{array}{ll}3 & (2 \%) \\
3 & (2 \%) \\
1 & (1 \%) \\
1 & (1 \%)\end{array}$ \\
\hline $\begin{array}{l}\text { Electric Resistance Heat (only) } \\
\text { Electric w/Propane Stove }\end{array}$ & $\begin{array}{r}184 \quad(44 \%) \\
1(0.25 \%)\end{array}$ & $\begin{array}{rr}19 & (16 \%) \\
0 & (0 \%)\end{array}$ \\
\hline
\end{tabular}


meating system. Radiant heat, as shown in iable 3.9, is nost often conbinac. with electric resistance heat (28 residences), rather than used as the oniy heating system (18 residences). $0 i 1$ heat is also used in combination with another heating system more often ( 9 residences) than as the only heating system ( 4 residences). Gas heating systems are used by $6 \%$ of the residences surveyed, with approximately half of the houses having electric resistance heat as a secondary source.

Table 3.9 also shows the number of residences with air conditioning (118) associated with the heating system(s) contained in the residence. All heat pump systems are assumed to have air-conditioning capability and represent $37 \%$ of the air conditioned residences. Of the remaining air-conditioned houses, 43 have electric forced air heating systems, 19 have only electric resistance heating systems, and the other 14 residences have a variety of heating systems.

Tabie 3.10 shows that in the older houses built before $1960,44 \%$ use only electric resistance heat while $24 \%$ use some gas or oil heating. Oniy $17 \%$ of

TABLE 3.10. Heating System Type by Year Residence Built

\begin{tabular}{|c|c|c|c|}
\hline Heating System & $\begin{array}{l}\text { Before } \\
1960 \\
(n=111) \\
\end{array}$ & $\begin{array}{l}1960 \text { to } \\
1978 \\
(n=160)\end{array}$ & $\begin{array}{l}\text { After } \\
1978 \\
(n=145) \\
\end{array}$ \\
\hline $\begin{array}{l}\text { Electric Forced Air (only) } \\
\text { Electric w/Electric Resistance Heat } \\
\text { Electric w/Radiant Heat }\end{array}$ & $\begin{array}{r}11 \% \\
6 \% \\
0 \%\end{array}$ & $\begin{array}{r}28 \% \\
6 \% \\
1 \%\end{array}$ & $\begin{array}{r}23 \% \\
0 \% \\
0 \%\end{array}$ \\
\hline $\begin{array}{l}\text { Heat Pump (only) } \\
\text { Heat w/Electric Resistance Heat } \\
\text { Heat w/Oil Heat } \\
\text { Heat } w / \text { Radiant Heat }\end{array}$ & $\begin{array}{l}5 \% \\
1 \% \\
1 \% \\
0 \%\end{array}$ & $\begin{array}{l}9 \% \\
1 \% \\
1 \% \\
1 \%\end{array}$ & $\begin{array}{r}11 \% \\
1 \% \\
0 \% \\
0 \%\end{array}$ \\
\hline $\begin{array}{l}\text { Radiant Heat (only) } \\
\text { Radiant } w / E l \text { lectric Resistance Heat } \\
\text { Radiant } w / 0 i l \text { Heat }\end{array}$ & $\begin{array}{l}4 \% \\
5 \% \\
1 \%\end{array}$ & $\begin{array}{r}5 \% \\
10 \% \\
0 \%\end{array}$ & $\begin{array}{l}4 \% \\
5 \% \\
0 \%\end{array}$ \\
\hline $\begin{array}{l}\text { Gas Heat (onTy) } \\
\text { Gas w/Electric Resistance Heat } \\
\text { oil Heat (only) } \\
0 i \text { w/Electric Resistance Heat }\end{array}$ & $\begin{array}{l}5 \% \\
8 \% \\
4 \% \\
5 \%\end{array}$ & $\begin{array}{l}5 \% \\
1 \% \\
0 \% \\
0 \%\end{array}$ & $\begin{array}{l}1 \% \\
0 \% \\
0 \% \\
0 \%\end{array}$ \\
\hline $\begin{array}{l}\text { Electric Resistance Heat (only) } \\
\text { Electric w/Propane Stove }\end{array}$ & $\begin{array}{r}44 \% \\
0 \%\end{array}$ & $\begin{array}{r}31 \% \\
1 \%\end{array}$ & $\begin{array}{r}55 \% \\
0 \%\end{array}$ \\
\hline
\end{tabular}


these older houses use an plectric forced air sysiem. This percentage more than doubles to 35\% for residences built between 1960 and 1978 . For houses buitt from 1960 to $1978,31 \%$ are heated only by electric resistance heat and 12\% by heat pump systems. In the newer homes, built after 1978, 55\% of the houses are heated only by electric resistance heat and $23 \%$ by electric forced air systems. Heat pump systems stili represent $12 \%$ of the heating systems, while oil and gas heating systems have fallen to $I_{\%}^{*}$ of the total.

Residences with less than $1000 \mathrm{ft}^{2}$ of conditioned space are primarily heated with electric resistance heat only $(66 \%)$, as shown Tabie 3.11. No heat pump systems are present in any of these smaller houses. The proportion of residences heated with electric forced air systems increases as the conditioned

TABLE 3.11. Heating System Type by Conditioned Area

\begin{tabular}{|c|c|c|c|c|}
\hline \multirow[b]{2}{*}{ Heating System } & \multicolumn{4}{|c|}{ Conditioned Area } \\
\hline & $\begin{array}{l}<1000 \mathrm{ft}^{2} \\
(n=49)\end{array}$ & $\begin{array}{c}1000-1500 \mathrm{ft}^{2} \\
(\mathrm{n}=129)\end{array}$ & $\begin{array}{c}1501-2000 \mathrm{ft}^{2} \\
(\mathrm{n}=111)\end{array}$ & $\begin{array}{c}>2000 \mathrm{ft}^{2} \\
(\mathrm{n}=127) \\
\end{array}$ \\
\hline $\begin{array}{l}\text { Electric Forced Air (oniy) } \\
\text { Electric W/Electric }\end{array}$ & $10 \%$ & $14 \%$ & $26 \%$ & $29 \%$ \\
\hline Resistance Heat & $2 \%$ & $2 \%$ & $4 \%$ & $6 \%$ \\
\hline Electric w/Radiant Heat & $0 \%$ & $1 \%$ & $0 \%$ & $1 \%$ \\
\hline $\begin{array}{l}\text { Heat Pump (onTy) } \\
\text { Heat w/Electric Resistance }\end{array}$ & $0 \%$ & $5 \%$ & $16^{2}$ & $9 \%$ \\
\hline Heat & $0 \%$ & $0_{\oplus}^{\infty}$ & $0 \%$ & $2 \%$ \\
\hline Heat w/0il Heat & $0 \%$ & $1 \%$ & $0 \%$ & $1 \%$ \\
\hline Heat w/Radiant Heat & $0 \%$ & $0_{\%}^{\circ}$ & $0 \%$ & $1 \%$ \\
\hline $\begin{array}{l}\text { Radiant Heat (only) } \\
\text { Radiant w/Electric }\end{array}$ & $6 \%$ & $7_{\%}^{\circ}$ & $5 \%$ & $1 \%$ \\
\hline $\begin{array}{l}\text { Resistance Heat } \\
\text { Radiant w/0iT Heat }\end{array}$ & $\begin{array}{l}2 \% \\
0 \%\end{array}$ & $\begin{array}{l}7 \% \\
0 \%\end{array}$ & $\begin{array}{l}8 \% \\
0 \%\end{array}$ & $\begin{array}{l}7 \% \\
1 \%\end{array}$ \\
\hline $\begin{array}{l}\text { Gas Heat (only) } \\
\text { Gas w/Eiectric Resistance }\end{array}$ & $6 \%$ & $2 \%$ & $3 \%$ & $4 \%$ \\
\hline Heat & $4 \%$ & $2 \%$ & $2 \%$ & $4:$ \\
\hline $\begin{array}{l}\text { Oit Heat (only) } \\
\text { Oil w/Electric Resistance }\end{array}$ & $2 \%$ & $O_{\infty}^{\infty}$ & $2 \%$ & $1 \%$ \\
\hline Heat & $2 \%$ & $2 \%$ & $1 \stackrel{\alpha}{\%}$ & $2 \%$ \\
\hline $\begin{array}{l}\text { Electric Resistance } \\
\text { Heat (only) } \\
\text { Electric w/Propane Stove }\end{array}$ & $\begin{array}{r}66 \% \\
0 \%\end{array}$ & $\begin{array}{r}57 \% \\
0 \%\end{array}$ & $\begin{array}{r}32 \% \\
0 \%\end{array}$ & $\begin{array}{r}30 \% \\
1 \%\end{array}$ \\
\hline
\end{tabular}




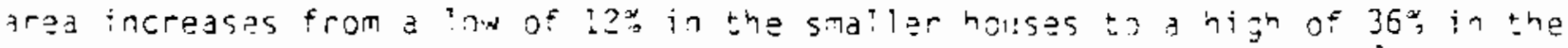
larger (>2000 $\mathrm{ft}^{2}$ ) houses. The proportion of houses with only electric resistance heat declines from $66^{\circ}$ in the smaller houses to a low of $31 \%$ in the larger houses. Heat pump systems are more prevalent in the upper two conditioned area categories $\left(>1500 \mathrm{ft}^{2}\right)$, while the other three categories--radiant, oil and gas heat--are spread among all sizes of dwellings.

Table 3.12 shows the geographic dispersion of the heating systems among the three geographic zones previously defined. Zone 1 contains more houses heated only by electric resistance (48\%) than does zone 2 (37.5\%), while zone 1 has fewer electric forced air systems (20\%) than zone 2 (34\%). Geographic zone 3 has more electric resistance heated only houses $(67 \%$ ) than the other two zones and less electric forced air systems (14\%). Also, no RI houses use gas heat in geographic zone 3 .

The distribution of heating systems across types of single-famity and multi-family dwellings is shown in Table 3.13. The proportion of houses

\section{TABLE 3.12. Heating System Type by Geographic Zone}

\begin{tabular}{|c|c|c|c|}
\hline Heating System & $\begin{array}{c}n 1 \\
(n=190) \\
\end{array}$ & $\begin{array}{c}\frac{\pi}{\pi 2} \\
(n=182) \\
\end{array}$ & $\begin{array}{c}\frac{\Perp 1}{\pi 3} \\
(n=44)\end{array}$ \\
\hline $\begin{array}{l}\text { Electric Forced Air (only) } \\
\text { Electric w/Electric Resistance Heat } \\
\text { Electric w/Radiant Heat }\end{array}$ & $\begin{array}{r}17 \% \\
3 \% \\
0 \%\end{array}$ & $\begin{array}{r}29 \% \\
4 \% \\
1 \%\end{array}$ & $\begin{array}{l}9 \% \\
5 \% \\
0 \%\end{array}$ \\
\hline $\begin{array}{l}\text { Heat Pump (only) } \\
\text { Heat w/Electric Resistance Heat } \\
\text { Heat } w / \text { Oil Heat } \\
\text { Heat } w / \text { Radiant Heat }\end{array}$ & $\begin{array}{r}9 \% \\
0.5 \% \\
0.5 \% \\
0 \%\end{array}$ & $\begin{array}{l}9 \% \\
9_{\infty}^{\infty} \\
0 \% \\
0 \%\end{array}$ & $\begin{array}{l}2 \% \\
0 \% \\
2 \% \\
2 \% \\
2 \%\end{array}$ \\
\hline $\begin{array}{l}\text { Radiant Heat (only) } \\
\text { Radiant w/Electric Resistance Heat } \\
\text { Radiant w/Oil Heat }\end{array}$ & $\begin{array}{r}7 \% \\
4 \% \\
0.5 \%\end{array}$ & $\begin{array}{l}2 \% \\
9 \% \\
0 \%\end{array}$ & $\begin{array}{l}2 \% \\
9 \% \\
0 \%\end{array}$ \\
\hline $\begin{array}{l}\text { Gas Heat (oniy) } \\
0 i 1 \text { w/Electric Resistance Heat } \\
\text { Oil Heat (only) } \\
\text { Gas w/Electric Resistance Heat }\end{array}$ & $\begin{array}{l}4 \% \\
4 \% \\
2 \% \\
0.2\end{array}$ & $\begin{array}{r}3 \% \\
2 \% \\
0.5 \% \\
2 \% \\
2 \%\end{array}$ & $\begin{array}{l}0 \% \\
0 \% \\
0 \% \\
0_{\alpha}^{\alpha} \\
2 \%\end{array}$ \\
\hline $\begin{array}{l}\text { Electric Resistance Heat (only) } \\
\text { Electric w/Propane Stove }\end{array}$ & $\begin{array}{r}48 \% \\
0 \%\end{array}$ & $\begin{array}{r}37.5 \% \\
0 \%\end{array}$ & $\begin{array}{r}65 \% \\
2 \%\end{array}$ \\
\hline
\end{tabular}


TABLE 3.13. Heating System Type by Type of Residence

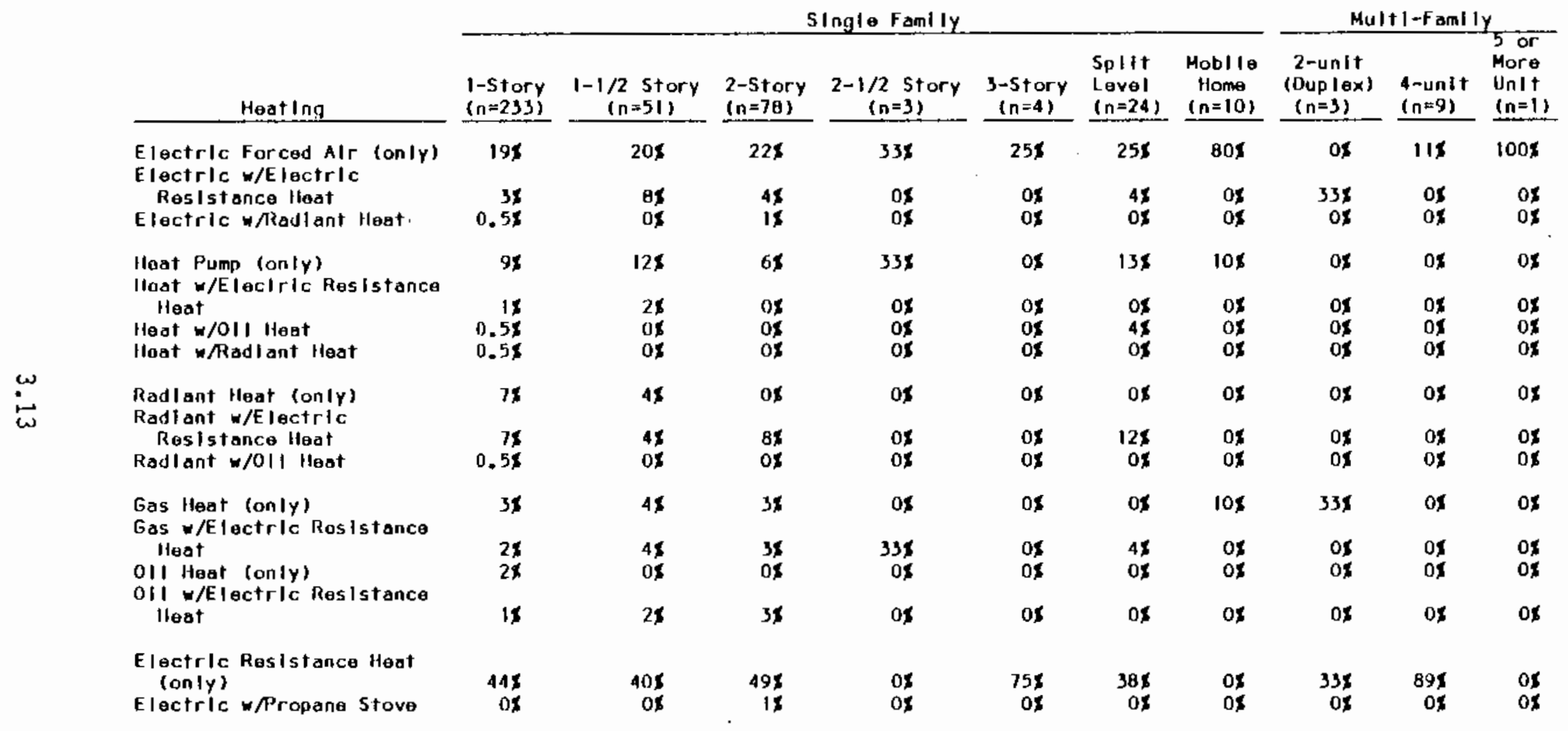


neated only by elactric resistance does not change nuch across tne singlefamily dwelling types, staying at $\sim 45 \%$. Likewise, the electric forced air system proportion stays at $\sim 25 \%$ across the single-family dwelling types. The major exception is that $80 \%$ of mobile homes in the survey have an electric forced air system.

In addition to the heating systems examined thus far, many residences had wood heating systems, fireplaces or stoves. The number of dwellings with at least one woodstove is 139 or $33 \%$ of the total number of residences. The distribution of these woodstoves by the heating system type previously defined is shown in Table 3.14. The table shows that $49 \%$ of the woodstoves are present in electric-resistance-heated residences. The residences with fireplaces number 199 or $48 \%$ of the total number of residences.

The number of residences without any wood heating system is 118 or $28 \%$ of the tota?. Table 3.14 shows that $54 \%$ of these residences also have electric

TABLE 3.14. Heating System Type by Wood Heating System

\begin{tabular}{|c|c|c|c|}
\hline & $\begin{array}{l}\text { With } \\
\text { Wood Stove } \\
(n=139) \\
\end{array}$ & $\begin{array}{l}\text { With } \\
\text { Fireplace } \\
(n=19 g) \\
\end{array}$ & $\begin{array}{l}\text { Without } \\
\text { Wood Heating } \\
(\mathrm{n}=118)\end{array}$ \\
\hline $\begin{array}{l}\text { Electric Forced Air (onIy) } \\
\text { Electric w/Electric Resistance Heat } \\
\text { Electric w/Radiant Heat }\end{array}$ & $\begin{array}{r}22 \% \\
6 \% \\
1 \%\end{array}$ & $\begin{array}{r}24 \% \\
5 \% \\
0 \%\end{array}$ & $\begin{array}{r}17 \% \\
2 \% \\
0 \%\end{array}$ \\
\hline $\begin{array}{l}\text { Heat Pump (only) } \\
\text { Heat w/Electric Resistance Heat } \\
\text { Heat w/0il Heat } \\
\text { Heat w/Radiant Heat }\end{array}$ & $\begin{array}{l}6 \% \\
0 \% \\
0 \% \\
1 \%\end{array}$ & $\begin{array}{r}12 \% \\
1 \% \\
0.5 \% \\
0.5 \%\end{array}$ & $\begin{array}{l}7 \% \\
1 \% \\
1 \% \\
0 \%\end{array}$ \\
\hline $\begin{array}{l}\text { Radiant Heat (only) } \\
\text { Radiant w/Electric Resistance Heat } \\
\text { Radiant } w / 0 i \text { Heat }\end{array}$ & $\begin{array}{l}2 \% \\
7 \% \\
0 \%\end{array}$ & $\begin{array}{r}7 \% \\
7 \% \\
0.5 \%\end{array}$ & $\begin{array}{l}3 \% \\
8 \% \\
0 \%\end{array}$ \\
\hline $\begin{array}{l}\text { Gas Heat (oniy) } \\
\text { Gas w/Electric Resistance Heat } \\
\text { oil Heat (only) } \\
\text { oil w/Electric Resistance Heat }\end{array}$ & $\begin{array}{l}1 \% \\
2 \% \\
1 \% \\
1 \%\end{array}$ & $\begin{array}{l}4 \% \\
4 \% \\
1 \% \\
1 \%\end{array}$ & $\begin{array}{l}4 \% \\
1 \% \\
0 \% \\
2 \%\end{array}$ \\
\hline $\begin{array}{l}\text { Electric Resistance Heat (only) } \\
\text { Electric w/Propane Stove }\end{array}$ & $\begin{array}{r}49 \% \\
1 \%\end{array}$ & $\begin{array}{r}32 \% \\
0.5 \%\end{array}$ & $\begin{array}{r}54 \% \\
0 \%\end{array}$ \\
\hline
\end{tabular}


resistance heating. fifven the totals shown in Table 3.11 , 208 . Wwellings (72: have some type of wood heating system $(416-118)$ and 40 residences $(10 \%)$ have both a woodstove and a fireplace $(139+199-298)$.

\subsection{INSULATION CHARACTERISTICS}

As part of the RI, the insulation material and type of insulation contained on or in the outside walls, under floors, and above the ceiling of the 416 houses in the survey were noted and entered into the CDB. The insulation materials specifically coded for were fiberglass, rock wool, synthetic, cellulose, and foam/polystyrene. Any other materials were noted as well. The insulation types that were specifically coded for in the RI were batt or blanket, loose or biown-in, board or slab, and multiple types. As with insulation materials, any other types were also noted. In addition, for floor insulation, an entry for perimeter insulation was allowed.

Tabie 3.15 presents the number of residences and the number of records in the CDB for wall, floor, and ceiling insulation. As the table shows, 390 residences (94\%) have an some insulation in at least some of the outside walls. These residences have an average of $7-1 / 2$ records per residence because the wall records are separated for each residence by the orientation of the wall, the wall construction type, insulation type, and location of the wall with respect to the various zones in the building. As shown in Table 3.15, 293 of the residences have floor insulation (70\%). Of these residences, $\sim 48 \%$ or 142 houses have more than one matarial or type of insulation under the floor. The number of residences with ceiling insulation is 383 (92\%), of which 83 have two materials or types of insulation while 4 residences have more than two

TABLE 3.15. Residences with Insulation

\begin{tabular}{|c|c|c|}
\hline Insulation Location & $\begin{array}{l}\text { Number of } \\
\text { Residences }\end{array}$ & $\begin{array}{l}\text { Number of } \\
\text { Records }\end{array}$ \\
\hline Wall Insuiation & 390 & 2996 \\
\hline Floor Insulation & 293 & 435 \\
\hline Ceiling Insulation & 383 & 672 \\
\hline
\end{tabular}


materials or types in the ceiling. In most cases these represented ceilings above separate conditioned zones with different insulation materials for each ceiling.

Table 3.15 shows 435 records or instances of floor insulation in the CDB. Table 3.16 lists these 435 instances of floor insulation by material and location of the insulation. The most common material and location combination was fiberglass insulation in a crawl space (31\%). The 100 entries for unknown materials on the ground are not surprising because slab insulation is difficuit to inspect. Likewise, the 51 entries for unknown materials under an overhang are not surprising because in many cases it was difficult to inspect a second story or higher insulation installation.

TABLE 3.16 Floor Insulation Material and Location

\begin{tabular}{|c|c|c|}
\hline $\begin{array}{c}\text { Floor } \\
\text { Insulation Materiat }\end{array}$ & Location & $\begin{array}{l}\text { Number of } \\
\text { Residences }\end{array}$ \\
\hline \multirow[t]{4}{*}{ Fiberglass } & In Crawt Space & 137 \\
\hline & On Ground & 2 \\
\hline & Under Overhang & 37 \\
\hline & In Unheated Basement & 38 \\
\hline \multirow[t]{2}{*}{ Rock Wool } & In Craw? Space & 4 \\
\hline & In Unheated Basement & 2 \\
\hline \multirow[t]{3}{*}{ Foam/Polystyrene } & On Ground & 5 \\
\hline & Under Overhang & 1 \\
\hline & On Perimeter & 8 \\
\hline \multirow[t]{4}{*}{ Other Materiais } & In Crawl Space & 4 \\
\hline & In Unheated Basement & 4 \\
\hline & Under Overhang & 1 \\
\hline & On Perimeter & 1 \\
\hline \multirow[t]{4}{*}{ Unxnown Material } & In Crawl Space & 18 \\
\hline & On Ground & 100 \\
\hline & Under Overhang & 51 \\
\hline & In Unheated Basement & 22 \\
\hline
\end{tabular}


The 383 residences with ceiling insidlation are divided into insulation material and type in Table 3.17. As noted above, 87 residences had more than one material or type of insulation present in the ceiling. For these 87 residences the insulation category chosen for the residence was determined by examining the net area covered by each ceiling and then choosing the insulation covering the largest area. The multiple materials and multiple-type category represents 15\% of the total. An example of this would be loose-fill rock wool over a fiberglass blanket. The largest category in Table 3.17 is fiberglass batt or blanket and the next most common is cellulose that is loose-fill or blown in.

TABLE 3.17. Ceiling Insulation Characteristics

\begin{tabular}{|c|c|c|c|}
\hline Insulation Material & Insulation Type & Number & $\begin{array}{c}\text { Percent } \\
\text { of } \\
\text { Total } \\
(n=383) \\
\end{array}$ \\
\hline \multirow[t]{3}{*}{ Fiberglass } & Batt/Blanket & 90 & $24 \%$ \\
\hline & Loose/Blown-in & 57 & $15 \%$ \\
\hline & Multiple Types & 2 & $0.5 \%$ \\
\hline \multirow[t]{2}{*}{ Rock Wool } & Batt/Blanket & 3 & $1 \%$ \\
\hline & Loose/Blown-in & 65 & $17 \%$ \\
\hline \multirow[t]{2}{*}{ Synthetic } & Loose/Blown-in & 6 & $2 \%$ \\
\hline & Board/Slab & 1 & $0.5 \%$ \\
\hline \multirow[t]{2}{*}{ Cellulose } & Batt/Blanket & 4 & $1 \%$ \\
\hline & Loose/BTown-in & 73 & $19 \%$ \\
\hline Foam/Polystyrene & Board/Siab & 3 & $1 \%$ \\
\hline \multirow[t]{2}{*}{ Multiple Materials } & Loose/BTowr-in & 5 & $1 \%$ \\
\hline & Multiple Types & 59 & $15 \%$ \\
\hline \multirow[t]{4}{*}{ Other Materials } & Batt/Blanket & 1 & $0.5 \%$ \\
\hline & Loose/Blown-in & 5 & $1 \%$ \\
\hline & Board/Slab & 4 & $1 \%$ \\
\hline & Other Types & 1 & $0.5 \%$ \\
\hline
\end{tabular}


The remaining tables dealing with ceiling insulation (Tables 3.18

through 3.21) are divided into the seven ceiling insulation material categories only, along with an entry for no insulation. Table 3.18 shows that the newer homes (constructed after 1978) have a higher percentage of residences with cellulose ceiling insulation (31\%) and a lower percentage with multiple materials (1\%) than the other two age groups. The percentage of houses with fiberglass and rock wool is not much different across the age categories.

In Table 3.19 the size category that differs the most from the other three is the smaller residence category $\left(<1000 \mathrm{ft}^{2}\right)$. The percentage of residences with uninsulated ceilings in this category is $20 \%$, while in the larger houses it is $5 \%$ to $9 \%$. Also in this category, the percentage of residences with cellutose ceiling insulation is $34 \%$, while in the larger houses this ranges from 13\% to $22 \%$. The other three categories have more fiberglass (31\% to $41 \%$ ) and rock wool (16\% to $18 \%$ ) ceiling insulation.

Table 3.20 examines the breakdown of ceiling insulation material by geographic zone. Geographic zone 3 (western Montana) has no residences with uninsulated ceilings and has a higher percentage of "other materials" (12\%) and

TABLE 3.18. Ceiling Insulation Material by Year Residence Built

\begin{tabular}{l} 
Ceiling \\
Insulation Material \\
\hline Fiberglass \\
Rock Woot \\
Synthetic \\
Cellulose \\
Foam/Polystyrene \\
Multiple Materials \\
Other Materials \\
No Insulation
\end{tabular}

\begin{tabular}{|c|c|c|}
\hline $\begin{array}{c}\text { Before } \\
1960 \\
(n=111)\end{array}$ & $\begin{array}{r}1960 \\
1968 \\
(n=160) \\
\end{array}$ & $\begin{array}{l}\text { After } \\
197 \mathrm{~B} \\
(n=145) \\
\end{array}$ \\
\hline $29 \%$ & $40^{\alpha}$ & $37 \%$ \\
\hline $14 \%$ & $18 \%$ & $16 \%$ \\
\hline $5 \%$ & 1\% & $1 \%$ \\
\hline $14 \%$ & $10 \%$ & $31 \%$ \\
\hline $0 \%$ & $1 \%$ & $1 \%$ \\
\hline $29 \%$ & $21 \%$ & $1 \%$ \\
\hline $3 \%$ & $3 \%$ & $5 \%$ \\
\hline $10 \%$ & $6 \%$ & $8 \%$ \\
\hline
\end{tabular}


TARLE 3.19. Ceiling Insulation Material hy Conditioned Area

\begin{tabular}{|c|c|c|c|c|}
\hline \multirow[b]{2}{*}{$\begin{array}{c}\text { Ceiling } \\
\text { Insulation Material } \\
\end{array}$} & \multirow[b]{2}{*}{$\begin{array}{l}<1000 \mathrm{ft}^{2} \\
(n=49) \\
\end{array}$} & \multicolumn{3}{|c|}{ Conditioned Area } \\
\hline & & $\begin{array}{r}1000-1500 \mathrm{ft}^{2} \\
(\mathrm{n}=129)\end{array}$ & $\begin{array}{c}1501-2000 \mathrm{ft}^{2} \\
(\mathrm{n}=111) \\
\end{array}$ & $\begin{array}{c}>2000 \mathrm{ft}^{2} \\
(\mathrm{n}=127) \\
\end{array}$ \\
\hline Fiberglass & $18 \%$ & $41 \%$ & $31 \%$ & $41 \%$ \\
\hline Rock Wool & $6 \%$ & $18 \%$ & $18 \%$ & $16 \%$ \\
\hline Synthetic & $0 \%$ & $2 \%$ & $1 \%$ & $2 \%$ \\
\hline Cellulose & $34 \%$ & $13 \%$ & $22 \%$ & $16 \%$ \\
\hline Foam Polystyrene & $0 \%$ & $2 \%$ & $0 \%$ & $1 \%$ \\
\hline Multiple Materials & $16 \%$ & $16 \%$ & $17 \%$ & $13 \%$ \\
\hline Other Materiais & $6 \%$ & $3 \%$ & $2 \%$ & $6 \%$ \\
\hline No Insulation & $20 \%$ & $5 \%$ & $9 \%$ & $5 \%$ \\
\hline
\end{tabular}

TABLE 3.20. Ceiling Insulation by Geographic Zone

\begin{tabular}{l}
$\quad$ Ceiling \\
Insulation Material \\
\hline Fiberglass \\
Rock Wool \\
Synthetic \\
Cellulose \\
Foam/Polystyrene \\
Multiple Materials \\
Other Materials \\
No insulation
\end{tabular}

rock wool $(25 \%)$ used for ceiling insulation than the other two geographic zones. Resioencas in geographic zone 1 have more fiberglass (43\%) and less cellulose (11\%) than residences in the other two zones.

As shown in Table 3.21, fiberglass ceiling insulation is the predominant insulation material used in all the single-family dwellings except split-level houses. For the split-ievel houses in the sample, cellulose ceiling insulation is more common than fiberglass or any other material. For the multi-family 
TABLE 3.21. Cefling Insulation Material by Type of Residence

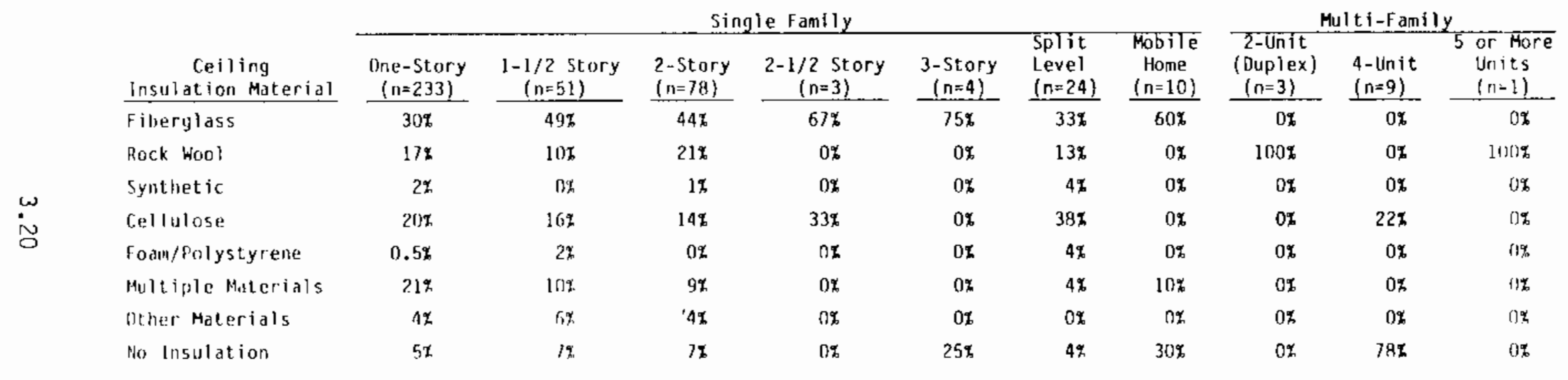


Hwellings, rock wool is the only zoiling insulation material car the duplexes and the five-unit or larger complex. Among the 4-unit multi-family dwellings, 78\% have no ceiling insulation.

\subsection{FOUNDATION CHARACTERISTICS}

The foundation is the structure that supports and couples a building with the ground. Three types of foundations are identified in the RI: crawl spaces, slab-on-grades, and basements. Four of the 416 residences had no foundation because they were upstairs units of a multi-family (apartment) structure. The other 412 residences had at least one foundation type. Table 3.22 details the seven combinations of foundation type found in residences surveyed by the RI. Overall, the most common foundation type is the crawl space $(67 \%$ of the houses), followed by the basement (42\%), and the slab-on-grade (25\%). (a) As the table shows, 287 or $70 \%$ had only one foundation type while 104 (25\%) had two types, and $21(5 \%)$ had all three foundation types. The remainder of this section shows how these foundation types are represented across the five general characteristics discussed in Section 3.1 .

\section{TABLE 3.22. Foundation Characteristics}

\begin{tabular}{|c|c|c|}
\hline Foundation Type & $\begin{array}{l}\text { Number of } \\
\text { Residences } \\
(n=416) \\
\end{array}$ & $\begin{array}{c}\text { Residences } \\
\text { (oercentage) }\end{array}$ \\
\hline Crawl Space (only) & 173 & 42 \\
\hline Crawl Space w/Basement & 49 & 12 \\
\hline Crawl Space w/Slab & 34 & 8 \\
\hline Craw Space w/Basement and Slab & 21 & 5 \\
\hline Slab-on-Grade (on Ty) & 30 & 7 \\
\hline Slab w/Basement & 21 & 5 \\
\hline Basement (only) & 84 & 20 \\
\hline No Foundation & 4 & 1 \\
\hline
\end{tabular}

(a) Due to the multiple foundation types in Table 3.22 , figures are not additive. 
Table 3.23 presents the distribution of foundation types by the yoar the residence was built. The results indicate that more residences have crawl spaces with basements in the older (before 1960) category (23\%) than in the newer (after 1978) category (6\%). There are no residences with oniy slab-ongrade foundations in the older category, while $18 \%$ of the residences in the newer category have this foundation type. Also of note is that the percentage of residences with only crawl space and only basement foundations remains fairly constant in all three categories.

The distribution of foundation types across size or conditioned-area categories is shown in Table 3.24. For residences with less than $1500 \mathrm{ft}^{2}$, $\sim 60 \%$ have only crawl spaces. The percentage of crawl-space-oniy residences declines to $19 \%$ for the largest-area category. Similarly, the slab-on-gradeonly houses make up $\sim 13 \%$ of the smaller area categories and only $3 \%$ of the larger-area category. In the largest-size category, $32 \%$ of the houses have a basement only, while in the smallest-size category $8 \%$ of the residences have a basement only. Combining all basement entries, including those with a basement as part of a multiple foundation type, Table 3.24 shows that the largest-size category has $72 \%$ of its residences with a basement compared with $18 \%$ of the smallest-size category.

TABLE 3.23. Foundation Type by Year Residence Built

\begin{tabular}{|c|c|c|c|}
\hline Foundation Type & $\begin{array}{l}\text { Before } \\
1960 \\
(n=111)\end{array}$ & $\begin{array}{c}1960 \text { to } \\
1978 \\
(n=150)\end{array}$ & $\begin{array}{l}\text { After } \\
1973 \\
(n=115) \\
\end{array}$ \\
\hline Crawl Space (only) & $41 \%$ & $44 \%$ & $39 \%$ \\
\hline Crawl Space w/Basement & $23 \%$ & $9 \%$ & $5 \%$ \\
\hline Craw Space w/Slab & $5 \%$ & $12 \%$ & $6 \%$ \\
\hline Crawl Space w/8asement and 5lab & $8 \%$ & $5 \%$ & $3 \%$ \\
\hline Slab-on-Grade (only) & $0 \%$ & $3 \%$ & $18 \%$ \\
\hline Slab w/Basement & $2 \%$ & $4 \%$ & $8 \%$ \\
\hline Basement (only) & $21 \%$ & $23 \%$ & $17 \%$ \\
\hline No Foundation & $0 \%$ & $0 \%$ & $3 \%$ \\
\hline
\end{tabular}


TABLE 3.21. Foundation Type by Conditioned Area

Conditioned Area

\begin{tabular}{|c|c|c|c|c|}
\hline Foundat i on Type & $\begin{array}{c}<1000 \mathrm{ft}^{2} \\
(n=49) \\
\end{array}$ & $\begin{array}{r}1000-1500 \mathrm{ft}^{2} \\
(n=129) \\
\end{array}$ & $\begin{array}{c}1501-2000 \mathrm{ft}^{2} \\
(n=111) \\
\end{array}$ & $\begin{array}{r}>2000 \mathrm{ft}^{2} \\
\quad(n=127) \\
\end{array}$ \\
\hline Crawl Space (only) & $59 \%$ & $60 \%$ & $38 \%$ & $19 \%$ \\
\hline Crawl Space w/Basement & $4 \%$ & $9 \%$ & $12 \%$ & $18 \%$ \\
\hline Crawl Space w/Slab & $2 \%$ & $7 \%$ & $15 \%$ & $6 \%$ \\
\hline Crawl Space w/Basenent and Slab & $4 \%$ & $2 \%$ & $4 \%$ & $9 \%$ \\
\hline Slab-on-Grade (only) & $13 \%$ & $12 \%$ & $5 \%$ & $3 \%$ \\
\hline Slab w/Basement & $2 \%$ & $1 \%$ & $2 \%$ & $13 \%$ \\
\hline Basement (only) & $8 \%$ & $9 \%$ & $24 \%$ & $32 \%$ \\
\hline No Foundation & $8 \%$ & $0 \%$ & $0 \%$ & $0 \%$ \\
\hline
\end{tabular}


The distrihution of foundatinn types within the throe geograohic zones is shown in Table 3.25. On a percentage basis for each foundation type, geographic zone 2 is intermediate between zone 1 and 3 and is more like geographic zone 3 than 1. In geographic zone 1, the region west of the Cascades, $54 \%$ of the residences have only crawl spaces for foundations while in geographic zones 2 and $3, \sim 30 \%$ of the residences have oniy crawl spaces. Also in zone 1, 11\% of the houses have only slab-on-grade foundations while no residences with this foundation type were found in zone 3, Western Montana. On the other hand, in zone $3,34 \%$ of the residences had a basement only while in zone $1,9 \%$ had basements only.

Table 3.26 displays the type of foundations within each dwelling type. Among the 1-story, single-family dwellings the most prevalent foundation type is the crawl space only (54\%). The crawl-space-only foundation aiso makes up $90 \%$ of the mobilie home foundations inspected. For the rest of the singlefamily dwelling types, the most common foundation is the basement, either alone or in combination with another type. All of these dwelling types have at ieast $49 \%$ of their total with a basement. In the large, 4 -unit or more, multifamily dwelling categories the major foundation type is the slab-on-grade only. All of the duplexes surveyed have a crawl space for a foundation.

\section{TABLE 3.25. Foundation Type by Geographic Zone}

\begin{tabular}{|c|c|c|c|}
\hline Foundation Tyoe & $\begin{array}{c}=1 \\
(n=190) \\
\end{array}$ & $\begin{array}{c}\# 2 \\
(n=182) \\
\end{array}$ & $\begin{array}{c}=3 \\
(n=44) \\
\end{array}$ \\
\hline Crawl Space (only) & $54: 0$ & $32 \%$ & $27 \%$ \\
\hline Craw1 Space w/Basement & $8 \%$ & $14_{\%}^{\circ}$ & $16_{\%}^{\circ}$ \\
\hline Crawl Space w/Slab & $11 \%$ & $7 \%$ & $2 \%$ \\
\hline Crawl Space w/Basement and Slab & $4 \%$ & $6 \%$ & $7 \%$ \\
\hline Slab-on-Grade (only) & $11_{\circ}^{\circ}$ & $5 \%$ & $0 \%$ \\
\hline STab w/Basement & $3 \%$ & $6 \%$ & $14 \%$ \\
\hline Sasement (on ly) & $9 \%$ & $28 \%$ & $34 \%$ \\
\hline No Foundation & $0 \%$ & $2 \%$ & $0 \%$ \\
\hline
\end{tabular}


TARLE 3.26. Foundation Type by Type of Residence

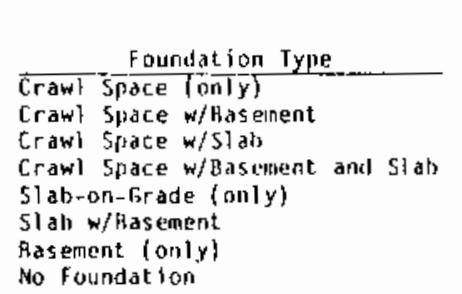

\begin{tabular}{|c|c|}
\hline $\begin{array}{l}1-5 \sin r y \\
\{n=233\}\end{array}$ & $\begin{array}{c}1-1 / 2 \text { story } \\
(n=51)\end{array}$ \\
\hline 547 & 23 \\
\hline $9 x$ & $23 z$ \\
\hline $8 x$ & $12 \%$ \\
\hline $5 x$ & $6 x$ \\
\hline $3 x$ & $16 \%$ \\
\hline $4 x$ & $2 \pi$ \\
\hline $17 x$ & $18 x$ \\
\hline $\operatorname{lig}$ & $0 \pi$ \\
\hline
\end{tabular}

\begin{tabular}{|c|c|c|}
\hline $\begin{array}{l}2-5 \operatorname{tor} y \\
(n=78)\end{array}$ & $\begin{array}{c}2-1 / 2 \text { story } \\
(n=3)\end{array}$ & $\begin{array}{c}3-5 \text { tory } \\
(n=4)\end{array}$ \\
\hline 278 & 334 & $0 \overline{2}$ \\
\hline 112 & $0 x$ & $25 \%$ \\
\hline $4 x$ & at & $0 x$ \\
\hline $4 x$ & $0 \%$ & $0 t$ \\
\hline 81 & $0 \%$ & 505 \\
\hline 102 & $33 \pi$ & 08 \\
\hline 367 & 337 & $25 \%$ \\
\hline $0 \pi$ & $0 \%$ & $0 \pi$ \\
\hline
\end{tabular}

\begin{tabular}{c} 
Split \\
Level \\
$\{n=24\}$ \\
\hline 172 \\
138 \\
218 \\
121 \\
42 \\
81 \\
$25 \pi$ \\
01
\end{tabular}

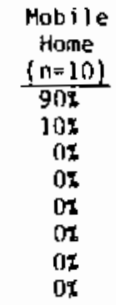

2-Unit

Duplex 4-unit

$(n=3)$

337

$0 \%$ ox

$05 \quad 44 x$

$07 \quad 228$

5 or Mare

Unit

$0 x$ 


\subsection{APOLIANIEE CHARACTERISTICS}

In addition to the structural and HVAC data gathered on each residence, information about the appliances was also collected. For most appliances, oniy the number present in each dwelling was recorded but for the following major appliances more information was requested: refrigerators, freezers, dishwashers and hot water heaters. This section discusses each major appliance and presents the total number of the other appliances.

Al] residences in the $R I$ had at least one hot water heater. Twenty residences had two hot water heaters and one residence had three for a total of 438 hot water heaters in the RI. The types of hot water heaters in the RI are shown in Table 3.27. Not surprisingly, $95 \%$ of the total are electric hot water heaters and $3 \%$ are gas heaters.

Table 3.28 shows the location of the hot water heaters at each house. Conditioned areas contain $64 \%$ of the hot water heaters and unconditioned areas contain $35 \%$. The hot water heaters can also be divided into seven groups by their capacity, in gallons, as shown in Table 3.29. The most common size of hot water heater found in the RI was 52 gallons $(57 \%)$. Of the 438 hot water heaters inspected, $184(42 \%)$ were insulated by a blanket or wrap on the tank, while $71(16 \%)$ were efficient unwrapped tanks with $R$-values greater than 3 . Also, 41 hot water heaters (9\%) had bottom boards, which are used to prevent heat loss into the floor. Only 9 hot water heaters were solar-assisted and only 8 had thermal traps to prevent heat losses into the connecting pipes.

\begin{tabular}{|c|c|c|}
\hline Tyoe & $\begin{array}{l}\text { Number of } \\
\text { HW Heaters } \\
\end{array}$ & $\begin{array}{c}\text { Percentage of } \\
\mathrm{HW} \text { Heaters }\end{array}$ \\
\hline Electric & 418 & 95 \\
\hline Natural Gas & 15 & 3 \\
\hline Propane & 1 & 0.25 \\
\hline Heat Pump-Add On & 1 & 0.25 \\
\hline Wood & 2 & 0.50 \\
\hline Unknown & 1 & 0.25 \\
\hline
\end{tabular}


TAR!E 3.29. Location of tot nater Heaters

\begin{tabular}{|c|c|c|}
\hline Location & $\begin{array}{l}\text { Number of } \\
\text { HW Heaters }\end{array}$ & $\begin{array}{c}\text { Percentage of } \\
\text { HW Heaters }\end{array}$ \\
\hline In Conditioned Area & 280 & 64 \\
\hline In Unconditioned Area & 129 & 29 \\
\hline In Craw1 Space & 27 & 6 \\
\hline Outside & 1 & 0.25 \\
\hline Unknown & 1 & 0.25 \\
\hline
\end{tabular}

TABLE 3.29. Capacity of Hot Water Heaters

\begin{tabular}{lcc} 
Capacity (gallons) & $\begin{array}{c}\text { Number of } \\
\text { HW Heaters }\end{array}$ & $\begin{array}{c}\text { Percentage of } \\
\text { HW Heaters }\end{array}$ \\
\cline { 2 - 3 } 1 to 10 & 4 & 1 \\
11 to 40 & 25 & 6 \\
41 to 51 & 42 & 10 \\
52 & 250 & 57 \\
53 to 70 & 28 & 6 \\
Greater than 70 & 22 & 5 \\
Unknown & 67 & 15
\end{tabular}

A total of 503 refrigerators are in the RI study. Of the 416 residences inspected, $333(80 \%)$ have one refrigerator, $82(20 \%)$ have more than one refrigerator, and one house, which was vacant, has no refrigerator. Table 3.30 detaits the various types or configurations of these refrigerators. Most of

TABLE 3.30. Types of Refrigerators

$\begin{array}{lcc}\text { Type } & \begin{array}{c}\text { Number of } \\ \text { Refrigerators }\end{array} & \begin{array}{c}\text { Percentage of } \\ \text { Refrigerators }\end{array} \\ \text { No Freezer Unit } & 11 & 2 \\ \text { Side Freezer Unit } & 91 & 18 \\ \text { Top Freezer Unit } & 329 & 65 \\ \text { Bottom Freezer Unit } & 23 & 5 \\ \text { Inside Freezer Unit } & 49 & 10\end{array}$


the refrigerators $\left(55^{\alpha}\right)$ have freezing comartinents on the top of the unit. Table 3.31 lists the locations of these refrigerators. Most ( $89 \%$ ) are locatec in conditioned areas of the residences.

A total of 320 freezers are in the RI study. Of the 416 residences inspected, $218(52 \%)$ have one freezer, $44(11 \%)$ have two freezers, 4 (1\%) have more than two freezers, and $150(36 \%)$ do not have any freezers. Table 3.32 shows that $64 \%$ are upright freezers with the remainder being chest freezers. The freezers' locations are shown in Table 3.33. Unlike the refrigerators, most freezers $(62 \%)$ are located in unconditioned areas.

A total of 342 dishwashers were present in the RI houses. One feature recorded about these dishwashers was the presence of an energy-saver switch. For 170 dishwashers an air-dry/cool-dry switch was present, and for 7 dishwashers a water miser switch was found. A total of 84 dishwashers have both switches on them. Thus, an energy-saver switch was present on $76 \%$ of the dishwashers. Also, 94 dishwashers $(27 \%)$ have a separate water heater element within the dishwasher. The other $73 \%$ either do not have this element or it could not be determined whether the dishwasher had the separate element.

Table 3.34 lists other appliances and pieces of equipment found in the inspected residences. The number of residences containing at least one of the

TABLE 3.31. Location of Refrigerators

\begin{tabular}{|c|c|c|c|}
\hline Location & $\begin{array}{c}\text { Number of } \\
\text { Refrigerators }\end{array}$ & $\begin{array}{l}\text { Percen } \\
\text { Refrig }\end{array}$ & $\begin{array}{l}\text { ntage of } \\
\text { gerators }\end{array}$ \\
\hline Conditioned Area & 446 & & 89 \\
\hline Unconditioned Space & 51 & & 10 \\
\hline \multirow{3}{*}{ TABLE 3.32} & 6 & & 1 \\
\hline & \multicolumn{3}{|c|}{ Types of Freezers } \\
\hline & $\begin{array}{l}\text { Number of } \\
\text { Freezers }\end{array}$ & $\begin{array}{r}\text { Percent age } \\
\text { Freezers } \\
\end{array}$ & of \\
\hline Upright Freezer & 205 & 64 & \\
\hline Chest Freezer & 115 & 36 & \\
\hline
\end{tabular}


TARLE 3.33. Location of Freezers

\begin{tabular}{lccc}
\multicolumn{1}{c}{ Type } & $\begin{array}{c}\text { Number of } \\
\text { Freezers }\end{array}$ & $\begin{array}{c}\text { Percentage of } \\
\text { Freezers }\end{array}$ \\
Conditioned Area & & 123 & 38 \\
Unconditioned Space & 178 & 56 \\
Outside & 17 & 5 \\
Crawl Space & 2 & 1
\end{tabular}

TABLE 3.34. Other Appliances/Equipment Found in RI Houses

\begin{tabular}{|c|c|c|c|}
\hline APPL I ANCE/EOU I PMENT & $\begin{array}{l}\text { Number of } \\
\text { Residonces }\end{array}$ & APPL I ANCE /EQU IPMENT & $\begin{array}{l}\text { Number of } \\
\text { Residences }\end{array}$ \\
\hline Electric Stove Top Eurner Unit. & 54 & Electroststic Precipitator & 19 \\
\hline Gos Stove Top Buener Unit & 3 & Wetl Pump_ & 94 \\
\hline Electric Range and Oven & 342 & Irrlgation Pump_ & 26 \\
\hline Gas Range and Oven & 10 & Power Saw/Wood Work Equlp. & 151 \\
\hline Electric Oven & 70 & Arc Nelder & 26 \\
\hline Gas Oven & 1 & Electric Ceramic Kiln & 3 \\
\hline Microwave Oven & 306 & Portable Heater & 24 \\
\hline Clothes Washer & 396 & Electric Pol Hester & 5 \\
\hline Electric Clothes Dryer. & 391 & Gas Pool Heater & 5 \\
\hline Ges Clothes Dryer & 7 & Outcoor Light Fixtures & 357 \\
\hline Water Softener & 43 & Greenhouse Light Fixtures & 7 \\
\hline Stereo & 362 & Greenhouse Heater - Electric & 4 \\
\hline Black and white T.V. & 142 & Toaster Oven & 5 \\
\hline Color T.V. & 390 & Instant Hot wax __..._._. & 5 \\
\hline Home Computer & 79 & Convection Oven & 5 \\
\hline Copy Mach I ne & 5 & $V C R$ & 19 \\
\hline Hat Tub/Jacuzzi & 27 & Electric Blanket & 5 \\
\hline Water Bed Heater & 114 & Mercury Vapor Light & 3 \\
\hline Health or Medical Eauip. & 5 & Fan & 11 \\
\hline Humidlier & 50 & Garbage Disposa! & 13 \\
\hline Dehumidlifier. & 2 & Air Compressor & 8 \\
\hline Bathtub/Jacuzz! & 2 & & \\
\hline
\end{tabular}


listed appliances is shown. The most common axpliances found in the 415 rouses are color television sets (94\%), clothes washers (95\%), and electric clothes dryers $(97 \%)$. Some residences contain more than one of the appliances. For example, 173 houses have more than one color T.V., 83 have more than one stereo, and 98 have more than one piece of wood working equipment.

\subsection{CRAWL SPACE INSPECTION RESULTS}

As discussed in Section 3.4, 277 houses have a crawl space in the RI. Of these 277 crawl spaces, 253 of them (91\%) were accessible and received a crawlspace inspection to identify moisture and/or insect problems. One hundred accessible crawl spaces had problems while 153 had no problems. Table 3.35 lists the number of times each problem was recorded by an inspector and the number of times each problem occurred in combination with a moisture probiem. As the table shows, moisture was the most common problem noted (75 times); 80 instances of other problems were recorded. Of these 80 problems, $50(62 \%)$ occurred in combination with a moisture problem.

The geographical dispersion of crawl space problems is shown in Tabie 3.36. Geographic zone 1 has the most accessible craw spaces in the RI, 174 out of $253(69 \%)$. Geographic zone 2 has an equal number of accessible crawl spaces with and without problems, while the other two zones have more crawl spaces without probiems.

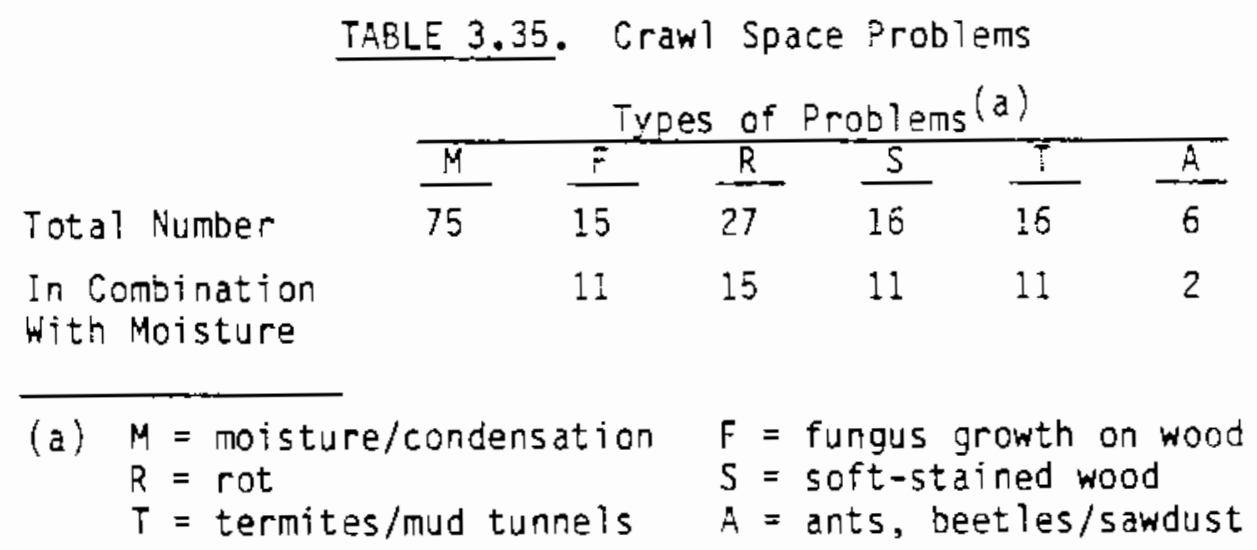


TABLE 3.35. Crawl Space Problems by reographiz Zone

$\begin{array}{ccccc}\begin{array}{c}\text { Accessible } \\ \text { Crawl Spaces }\end{array} & \frac{\left(\begin{array}{c}\# 1 \\ (n=174)\end{array}\right.}{37 \%} & \frac{c}{\# 2} \begin{array}{c}(n=58) \\ \text { With Problems }\end{array} & & \begin{array}{c}\# 3 \\ (n=21)\end{array} \\ \text { Without Problems } & 63 \% & & 50 \% & 29 \% \\ 71 \%\end{array}$

In the accessibie crawl spaces, the presence of insulation and of some type of vapor barrier was also recorded. As Table 3.37 shows, the smallest percentange is accessible crawl spaces with insulation and problems. The largest percentage is accessible crawl spaces with insulation and without problems. More problems were found in crawl spaces without insulation than in the crawt spaces with insulation.

Table 3.38 presents the percentage of crawl spaces with and without problems for those crawl spaces with and without vapor barriers. For those crawl spaces with a vapor barrier, most $(64 \%)$ have no problems. Crawl spaces without a vapor barrier had more problems $(46 \%)$ than those with a vapor barrier (36\%).

TABLE 3.37. Crawl Spaces Problems by Presence of Insuiation

\begin{tabular}{|c|c|c|}
\hline $\begin{array}{c}\text { Accessibie } \\
\text { Crawl Spaces }\end{array}$ & $\begin{array}{c}\text { With } \\
\text { Insulation } \\
(n=137) \\
\end{array}$ & $\begin{array}{l}\text { Without } \\
\text { Insulation } \\
(n=116)\end{array}$ \\
\hline With Problems & $36 \%$ & $43 \%$ \\
\hline Without Problems & $64 \%$ & $57 \%$ \\
\hline
\end{tabular}

TABLE 3.38. Crawl Space Problems by Presence of Vapor Barriers

\begin{tabular}{|c|c|c|}
\hline $\begin{array}{c}\text { Accessible } \\
\text { Crawl Spaces }\end{array}$ & $\begin{array}{c}\text { With Vapor } \\
\text { Barrier } \\
(n=163)\end{array}$ & $\begin{array}{l}\text { Without } \\
\text { Vapor } \\
\text { Barrier } \\
(n=90) \\
\end{array}$ \\
\hline With Problems & $36 \%$ & $46 \%$ \\
\hline Without Problems & $64 \%$ & $54 \%$ \\
\hline
\end{tabular}




\subsection{PECOMMENDATIONS}

If an attempt is made either to inspect the 31 residences that were not inspected or to update any RI data in the COB, the data should be obtained during maintenance visits to minimize visits to the residences.

Due to the large amount of RI data stored in the CDB, a code booklet or guide to these data should be written to aid any analysts attempting to use the information. Making the RI data more accessible to the analyst should be a high priority concern to all in the ELCAP. Without knowing the structural features of the residences or the appliances being used in the house, an analyst does not have the complete energy use picture. Thus, dissemination and ease of use of the RI data are very important. 


\section{REFERENCES}

Bonneville Power Administration (BPA). 1986. Procedures Manual for ELCAP Residential Building Characteristics Survey. D $\overline{0 E / B P-13795-9, ~ B P A, ~ P o r t l a n d, ~}$ oregon.

R.1 
.

.

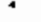

.

. 
APPENDIX A

QUALITY ASSURANCE OF RESIDENTIAL INSPECTIONS 


\section{QUALITY ASSURANCE OF RESIDENTIAL INSPECTIONS}

The following is a list of the major quality assurance (QA) tasks performed at PNL on each inspection:

- Look at cover sheet and check the PX\# on inspection with that in the status reports. Note any discrepancies and resolve them.

- Note receipt of inspection on list of outstanding inspections, and check to see if all floor plans and forms are present in incoming inspections.

- Note date of site visit by ECI and the PX\# on list for FIXNOTES computer data base update.

- Examine floor plan(s) to become familiar with the layout scheme and zoning of residence.

- Check questions 17-20 (heating systems) on iorms to verify that the correct zoning scheme was used and that all systems are correctly marked on the floor plan(s).

- Given floor plan(s) and pictures, verify that the first 4 questions (type of house or multi-family unit, garage type, and year built) were answered correctly.

- Check floor plan(s) to see that answers to the following parts of question 5 (windows) were entered correctily on the forms: orientation, location, and gross area. The gross area can be calculated from the floor plan for each entry on the form. Any discrepancies should be noted on a separate QA list; if the solution is obvious, the original entry should be changed and documented accordingly. The floor plan(s), according to ECI, are the original and correct representation of the residence, and if any discrepancies occur between the forms and the floor plan(s), the floor plan(s) information overrides the form entry. 
- Check floor plan(s) to sea that the information far question 5 (doors) on location, orientation, and gross area agrees with the entries on survey form. The same procedure is used here as for question 5 (windows) above. In addition, the entry for glass area for doors should agree with an entry in question 5 (windows). If not, add it to question 5 after determining correctness of glass area from floor pian.

- The entries for question 7 (walls) are very important for calculating the residence's U-value and usually were the hardest to analyze. The entries checked for each wall listed are construction (if possible to tell from floor plan), location, gross area, window/door area, and net area. The gross area, given the location of the wall, is the key data point in the $Q A$ check of the walls. In some cases, the height of the walls was not noted on the floor plan or forms, in which case an attempt was made to use common heights $\left(8^{\prime}, 71 / 2^{\prime}, 7^{\prime}\right)$ to arrive at the gross area using the lengths shown on the floor plan. If the wall gross area could not be determined, it was noted on the QA list and an attempt was made to figure it out using logical assumptions.

The most difficult buildings in which to check all gross areas are those with vaulted ceilings, partial attics with kneewalls, and very complex floor plans. If information critical to determining the gross wal1 area is missing, then the inspection is returned to ECI alang with the QA list noting the missing information. After return of these from ECI, another attempt to determine the correct figure for gross wall area is made. The inspectors' numbers for gross wall area are accepted at this point uniess a more logical value can be obtained from tine floor plan.

In addition to the gross area, the window/door area entry is checked to make sure it is correct given the gross area data in questions 5 and 6 . A check is also made to see that the net area equals the gross area minus the window/door area. The wall entry for gross area consumes the most $Q A$ time and is the most thoroughly checked figure in the form. 
- The entries for question 8 (ceiting/roof) that are checked are type, location, and net area. If the residence has a vaulted ceiling, the vault height is needed to check the ceiling net area entry. If it is not noted, the inspection is returned to ECI for clarification.

- Question 9 (attic ventilation) is simply checked to see if entries are made.

- Question 10 (number of conditioned levels) is checked for accuracy using the floor plans.

- Question 11 (area) is checked against the floor plan for both conditioned and unconditioned zones and subzones.

- Question 12 (volume) is checked using the areas in question 11 and the wall heights used in determining the gross wall areas in question 7 .

- Question 13 (rooms) is checked to make sure all unconditioned areas on the fioor plan (and noted in questions 11 and 12) are included in the correct place on this form.

- Questions 14 (interior air circulation) and 15 (mechanical ventilation to outside) are simply checked to make sure they are filled out.

- Question 10 (floors) has three entries that are checked: type, location, and floor area/perimeter. Again, the floor plan is used to judge the validity of these entries with the floor area also being checked with question 11 (area). In some cases, the area is needed and in other cases the perimeter is needed. If the wrong one is on the form, it is changed; if the perimeter was figured incorrectly, it is also corrected, if possible. A common mistake for the perimeter entry is that an unconditioned zone perimeter for a garage or other space is included when it is not supposed to be.

- Questions 17-20 (heating systems) and question 21 (AC systems) are examined to make sure the correct system code, location, and zone served are recorded. The floor plan is examined to note the location 
znt zone served. The ciel type and system type for heating systems is examined to understand the nature of the system and the zoning breakdown of the residence.

- Question 22 (duct/piping) is checked to make sure the associated system entry is in agreement with the heating and/or cooling system listed in questions 17-21.

- For questions 23-25 (hot water heater, refrigerators/freezers and dishwashers) the location entry is examined to ensure consistency with the floor plan and the zoning set up for the residence.

- Question 26 (appijances) is examined to ensure that an entry was made to all fields on the summary sheet.

- Question 27 (foundation) has four entries that are checked: type, material, below grade depth, and perimeter length. The type and material has to make sense with the location of the foundation and entries for the floors. The below-grade-depth entry is very useful in the wall gross area calculations and should be consistent with those figures. The perimeter length in some cases, such as basements and slab-on-grade houses, should be similar to the entry for the perimeter in the floor question. All differences should be logical and discrepancies noted on the QA Iist. Corrections are made from the floor plan if possible.

- Questions 28-32 (crawl space) are glanced at to make sure they are fjlled in for residences with crawl spaces, as noted in question 27 , and to make sure they are not answered for those residences without any crawl space.

- The modification and addition questions are glanced at to ensure that an entry was made to ail fields on the summary sheets.

- All pictures and coments are examined to make sure that information that could aid in determining any questionable entries is not overlooked. 
These procedures are appliad to each inspection as it is examined, and zny discrepancies are noted on the $Q A$ list. If any major problems are found, the inspection and QA list are returned to ECI in hopes of clearing them up. The inspections returned to ECI are so noted on the list of outstanding inspections. Those taken to data processing are marked off this list. If the data processing team has any questions, the inspection is re-examined to determine the correct entry into the CDB. 


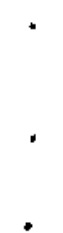


PNL -6429

UC -350

\section{$\underline{\text { DISTRIBUTION }}$}

No. of

Copies

\section{OFFSITE}

2 DOE/Office of Scientific and Technical Information

2 R. A. Gillman Bonneville Power Administration End-Use Research Section

P.0. Box 3621-RPEE

Portland, OR 97208

M. E. Taylor

Bonneville Power Administration

End-Use Research Section

P.0. Box 3621-RPEE

Portland, OR 97208

S. G. Hauser

Battelle Portland Office 500 NE Multnomah, Suite 650

Portland, OR 97232
No. of

Copies

W. M. Warwick

Battelle Portland office

500 NE Multnomah, Suite 650

Portland, OR 97232

ONSITE

12 Pacific Northwest Laboratory

C. C. Connor

R. G. Pratt

W. F. Sandusky (4)

G. M. Stokes

Publishing Coordination

Technical Report Files (5) 


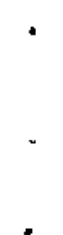

